\title{
AFTER 40 YEARS: REVISITING CEIBAL TO INVESTIGATE THE ORIGINS OF LOWLAND MAYA CIVILIZATION
}

\author{
Takeshi Inomata, ${ }^{a}$ Daniela Triadan, ${ }^{\mathrm{a}}$ and Kazuo Aoyama ${ }^{\mathrm{b}}$ \\ ${ }^{a}$ School of Anthropology, 1009 East South Campus Drive, University of Arizona, Tucson, Arizona 85721-0030 \\ ${ }^{\mathrm{b}}$ Faculty of Humanities, Ibaraki University, Bunkyo 2-1-1, Mito, Ibaraki 310-8512, Japan
}

\begin{abstract}
The Ceibal-Petexbatun Archaeological Project has been conducting field investigations at the lowland Maya site of Ceibal since 2005. Previous research at this site by Harvard University allowed us to develop detailed research designs geared toward specific research questions. A particularly important focus was the question of how lowland Maya civilization emerged and developed. Comparison with contemporaneous sites in central Chiapas led us to hypothesize that the residents of Ceibal established a formal spatial pattern similar to those of the Chiapas centers during the Middle Preclassic period (1000-350 B.C.). Through excavations of important elements of this spatial pattern, including a probable E-Group assemblage and large platforms, we examined how the Ceibal residents participated in interregional interactions with Chiapas, the Gulf Coast, and other areas, and how construction activities and architecture shaped the course of social change.
\end{abstract}

\section{INTRODUCTION}

How did the lowland Maya build their communities in the rapidly changing social environment of southern Mesoamerica during the Preclassic period? As small villages in the tropical lowlands grew into expansive centers with political authorities and large temple pyramids, people created and negotiated various identities of everlarger populations and ideologies of increasing social inequality through interactions with surrounding groups. Scholars hotly debate this process. Some argue that the lowland Maya received profound inspirations from the precocious Gulf Coast Olmec about ideas of rulership, deities, rituals, and architecture. Others are strongly opposed to this model of foreign influence, contending that it was essentially a local process or that the interactions with their neighbors were more symmetrical. More recently, researchers are emphasizing the importance of examining processes and contexts of interregional interactions instead of trying to determine the direction of influence. Scholars advocating this view have been exploring how the lowland Maya selected, adopted, and reinterpreted social and material elements derived from their neighbors and how they created and contributed certain ideas and practices. Located near the southwestern edge of the Maya lowlands, Ceibal (also known as Seibal) is a key site in the study of this question (Figure 1). This problem concerns one of the central issues in archaeology-political negotiation and transformation in broad interregional contexts, leading to the emergence of political centralization and social inequality (Algaze 1989; Dietler 1997; Joyce 1993; Stanish 2001; Yoffee 2004).

E-mail correspondence to: inomata@email.arizona.edu
The Ceibal-Petexbatun Archaeological Project has been examining this question through field work at Ceibal since 2005. The papers in this Special Section of Ancient Mesoamerica report the main results of this research and discuss their contributions to the study of origins of Maya civilization. The present article serves as a general introduction to this Special Section by reviewing relevant theoretical and historical issues, as well as the goals and research designs of the project, and by providing an overview of its field work.

\section{THEORETICAL BACKGROUND}

\section{Origins of Lowland Maya Civilization}

Theories on external relations of early lowland Maya society partly concern views on the nature of the so-called Olmec civilization. Some scholars have proposed that the Gulf Coast Olmec, as "la cultura madre," influenced other Mesoamerican societies and shaped the course of later development (e.g., Caso 1942; Clark and Pye 2000; Diehl 2004; Diehl and Coe 1995). This position may be related to more general archaeological views that emphasize the diffusion of cultural traits, migrations of people, and coreperiphery relations (e.g., Kardulias 1999; Rouse 1986). Others have argued for mutual interactions between "culturas hermanas," which resulted in shared art styles and the parallel development of political centralization in various regions (Demarest 1989; Flannery 1968; Grove 1997; Hammond 1989; Marcus and Flannery 1996). This school may be associated with a general archaeological trend that focuses on mutual interactions and local processes (e.g., Binford 1965; Renfrew and Cherry 1986). The 


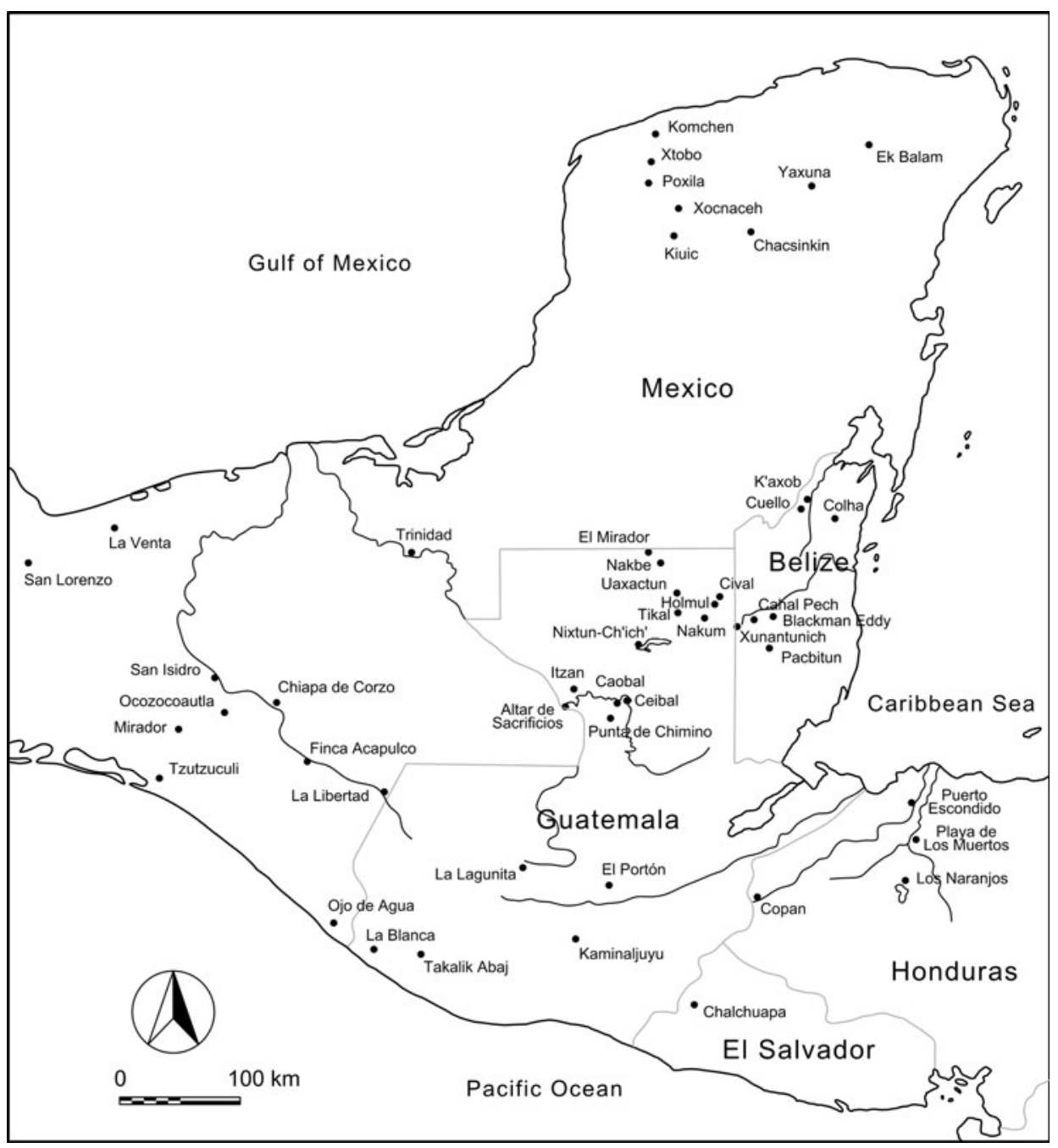

Figure 1. Map of the Maya lowlands and surrounding regions with the locations of Preclassic sites. Map by Inomata.

debate also involves the question of what the term "Olmec" means, including an ethnic group, specific art styles, and groups with shared practices (Grove 1989).

Recent investigations at the Gulf Coast center of San Lorenzo have reinvigorated this debate. Evidence of a large settlement and substantial constructions at this center has suggested to some that the Gulf Coast Olmec enjoyed a significantly higher degree of labor mobilization and political centralization than their contemporaries (Cyphers 1997, 2004; Symonds et al. 2002). Through compositional analysis of ceramics with Olmec motifs, Blomster et al. (2005) have proposed that San Lorenzo was the primary exporter of these vessels, reflecting San Lorenzo's far-reaching influence. Re-evaluation of migrations among a broader archaeologist community has also encouraged this trend (e.g., Anthony 1990; Cameron 1995). These data, however, fail to convince those who favor the mutual-interaction model, and some believe that the procedure and interpretation of the compositional analysis are problematic (Sharer et al. 2006).

The lowland Maya were the last major group in Mesoamerica to adopt ceramics and sedentary ways of life. The earliest evidence of ceramics and villages in the Maya lowlands appears around 1000 B.C. in the Belize valley, northern Belize, the central lowlands, and the Pasion region (Cheetham 2005; Garber et al. 2004). Whereas Andrews (1990) has suspected migrations of first villagers from Chiapas and the Guatemalan highlands, where there were longer histories of ceramic use and sedentism, Clark and Cheetham (2002) have emphasized the continuity of occupation by the local Maya, who underwent a transition from mobile ways of life to sedentism. For the subsequent social change in the Maya lowlands, Clark (Clark and Hansen 2001) argues for the importance of influence from the Gulf Coast Olmec, by pointing out the possible spread of standardized architectural complexes from the southern Gulf Coast and the Chiapas highlands to the Maya lowlands. Some iconographic studies imply that there was a strong continuity from the Preclassic Olmec to the Classic Maya in the notions of rulership, deities, and associated symbols (Fields 1991; Freidel 1990; Taube 1996, 1998). For example, the recently discovered Late Preclassic murals at San Bartolo in the central Maya lowlands show deities with probable Olmec features (Saturno et al. 2005).

Hansen (2005), however, counters that the large Maya centers in the Mirador Basin represent a local development and were in competition with the Gulf Coast Olmec during the late Middle Preclassic period (700-350 B.C.). A painted text found at San Bartolo dates to 
ca. 300 B.C., which makes it one of the earliest texts with relatively secure dates in Mesoamerica (Saturno et al. 2006). This finding indicates that the lowland Maya may not have been simple recipients of innovations by other groups, but they may have actively contributed to the early process of cultural development.

While this heated debate continues, an increasing number of scholars are recognizing that we need to move beyond the dichotomized views of the mother culture and sister cultures. These researchers address complex patterns of interactions among various groups with different social and political organization, as well as the roles of agents in specific historical contexts (Lesure 2004; Pool 2007:17; Stark 2000). Underlying this view is the growing emphasis on the agency of the people involved, on their practices as a focus of inquiry, and on the historical contexts and dynamics surrounding their actions. Instead of conceptualizing certain cultural elements moving unidirectionally, we need to examine how people chose to participate, or not to participate, in interregional interactions; how they adopted, rejected, or modified certain elements; in what kind of social contexts they did so; and how different groups and individuals, such as elites, non-elites, and kin- or gender-based groups, acted differently. For this purpose, we need to scrutinize: (1) what kind of exchange of material goods, as well as shared architectural, artifactual, and iconographic styles, occurred across a wide area through different time periods; (2) in what kind of social contexts they occurred-for examples, whether in egalitarian or hierarchical communities, and whether in times of social stability or change; and (3) whether the use of such materials and styles is associated with specific social groups.

\section{Community and Architecture}

A central question concerning the development of lowland Maya civilization is the process of community-building. Although scholars continue to debate concepts of community, a definition particularly relevant to our research states that a community is a group of interacting people with a sense of belonging and shared values (Anderson 1991; Cohen 1985; Crow and Allan 1994). This does not mean that a community is a homogenous social unit with a monolithic system of values. Any community involves internal heterogeneity, competing interests, and power relations. In other words, a community is not given or natural. Researchers need to examine how communities are socially constructed in specific historical contexts. Like any society, Preclassic Maya society must have involved multiple nesting and cross-cutting communities, but the type of community central to our research is one consisting of people living close to each other in a settlement and its surroundings, which, in the latter part of the Preclassic period, largely overlapped with a political unit centered around the ruling authority. While such communities exhibited a certain level of cohesion and order, they doubtless involved constant negotiation involving competing claims and different attitudes (Canuto and Yaeger 2000; McGuire 1992).

People's physical actions, material objects, and the natural and built environments play critical roles in the process of communitybuilding. Nevertheless, we should not assume that such objects and places record or transmit fixed, monolithic meaning in a mechanistic manner. A more productive approach in archaeological studies should be to examine how certain actions, objects, and places became points or hubs of manipulation of, impositions of, or resistance to certain meanings and how people engaged with them (Lesure 1999; Mills 2004; Inomata 2006, 2013; Weiner 1992:
99-100). Although the ways people engage in symbols and materials are diverse and historically contingent, it is useful to highlight certain common patterns. A case in point is the wide use of material symbols representing shared community identities and marking difference from other groups as seen in the use of flags and monuments in modern nationalism. The spread of increasingly homogeneous Mamom and Chicanel ceramics throughout the Maya lowlands might have represented comparable practices (Rice and Sharer 1987). Another pattern is the privileged claim of exotic symbols or skilled crafts by small groups (Helms 1998; Inomata 2001). Examples may include the use of Teotihuacan symbols by the Classic Maya (Braswell 2003; Grove and Gillespie 1992; Stone 1989).

As we examine the transformation of communities, we also need to pay attention to how the use or claim of objects, places, and symbols change. A commonly observed process is the appropriation of communal symbols and practices by privileged groups (Bloch 1986). The importance of the Maize God in elite rituals among the Classic Maya, and possibly their predecessors, may represent such appropriation of commonly held beliefs and practices (Taube 1985, 1996). A contrasting process is the elevation of symbols and practices originally associated with small groups to the communal sphere. The worship of dynastic ancestors in public ceremonies among the Classic Maya possibly had its roots in such processes during the Preclassic period (McAnany 1995). Interactions with external groups often play a critical role in such processes of community-building and political negotiation. Contrast or opposition with other groups may stimulate certain types of communal or ethnic identities, promoting notions of unified or bounded groups (Anderson 1991; Inomata 2014; Inomata and Triadan 2009; Jones 1997). In many cases, elites act as central figures in such interactions, taking political, ideological, or economic advantage of privileged access to foreign peoples, goods, and symbols (Earle 1987; Helms 1988; Junker 1993). External contacts can also lead, however, to the destabilization of hierarchical order or the subversion of power.

Stone monuments and art objects in so-called Olmec styles have figured prominently in the traditional studies of interregional interactions in Mesoamerica, but the role of architecture and space has recently become an important subject of scholarly inquiry. Buildings and settlement layouts in one sense reflect preexisting ideas and meanings (Ashmore and Sabloff 2002; DeMarrais et al. 1996; Kowalski 1999; Sugiyama 1993). At the same time, the built environment conditions people's actions and interactions through unyielding physical presence and shapes perception and experience through the multiple meanings and memories attached by different agents (Barrett 1994; Bradley 1993; Inomata and Coben 2006; Moore 1996; Smith 2003). Following Foucault (1977), Love (1999) has argued that the monumental architecture that developed in Middle Preclassic Mesoamerica created differentiated spaces, which shaped people's actions and movements and imposed notions of appropriate behavior. The importance of architecture is also clear in the analysis of Preclassic Maya sites by Ringle (1999), who suggests that architecture set stages for performance, through which buildings and places gained their own history and meaning. We need to keep in mind that the construction of large buildings during the Preclassic period represented unprecedented social experiments. Some monumental buildings may not have been simply the end results of political development, but such construction projects may have stimulated certain social changes, sometimes in unintended ways (Joyce 2004). Thus, architecture is an active constituent in social processes. By the same token, similar 
architectural styles do not signify blind adoption of cultural influence from different areas. We need to examine how people reinterpreted and modified the use and meaning of architecture inspired by other groups and how new built forms affected people's practice and experience.

\section{CEIBAL AND ITS NEIGHBORS}

\section{Previous Work}

Located in the Pasión region, Ceibal is arguably the most important site in the southwestern Maya lowlands (Figure 1). From 1964 through 1968, Harvard University carried out the first large-scale investigations at this site, including: mapping, extensive excavations of monumental buildings (Smith 1982; Willey 1990; Willey et al. 1975); epigraphic studies (Graham 1990); survey and excavations in the peripheries (Tourtellot 1988); and the analysis of ceramics and other artifacts (Sabloff 1975). Along with the earlier investigations at the nearby site of Altar de Sacrificios (e.g., Adams 1971; Willey 1973), these explorations of Ceibal marked milestones in the history of Maya archaeology. Harvard researchers uncovered one of the earliest ceramic complexes in the Maya lowlands at Ceibal and Altar de Sacrificios (Real-Xe), dating to the early Middle Preclassic (1000-700 B.C.). Their research showed that, within the large expanse of Ceibal, the area named Group A was the focus of this early occupation. During the following Escoba-Mamom (700-350 B.C.) and Cantutse-Chicanel (350 B.C.-A.D. 200) phases, Ceibal grew to be the largest ceremonial center in the Pasión region, with imposing temple pyramids. Group D, located on top of a steep hill, became an important focus of elite construction activity during the Terminal Preclassic period (75 B.C.-A.D. 200). Except for deep plaza pits, however, the Harvard investigations focused primarily on upper layers of buildings dating to the Classic period (A.D. 200-950), and much of the substantial Preclassic construction remained to be explored (Hammond 1984; Tourtellot and Hammond 2007). Following the early explorer, Maler (1908), the Harvard archaeologists adopted the spelling of Seibal for this site name, whereas Guatemalan scholars favored the correct Spanish spelling of Ceibal. To avoid the coexistence of different spellings, we decided to use the site name of Ceibal when we initiated the Ceibal-Petexbatun Archaeological Project.

It was not until the 1980s that the Pasión region became a target of intensive investigations again. Houston (1993) conducted his dissertation research in the Petexbatun region, which led to the Petexbatun Regional Archaeological Project led by Demarest, Houston, and Juan Antonio Valdés from 1989 through 1994 (Beach and Dunning 1997; Brady 1997; Brady et al. 1997; Demarest 1997, 2006; Dunning et al. 1997, 1998; Emery 1997; Foias and Bishop 1997, 2013; Inomata 1997, 2007; Inomata and Stiver 1998; Palka 1997; Wright 1997, 2006). Johnston (2004, 2006) investigated Itzan and its surroundings, and Just (2006) reexamined the monuments of Ceibal and Machaquila. The Proyecto Atlas Arqueológico directed by Laporte expanded their research in southeastern Peten into the adjacent Pasión area, which led to a collaborative project with the Spanish team at Machaquila (Ciudad Ruiz and Lacadena 2006, 2008). After the completion of the Petexbatun Project, Demarest started the excavation of Cancuen (Demarest 2013; Demarest et al. 2014, 2016; Kovacevich 2007, 2011, 2013; Woodfill 2010, 2011; Woodfill and Andrieu 2012; Woodfill et al. 2012). Inomata continued excavations at Aguateca with Triadan, Ponciano, and Aoyama, which started as part of the Petexbatun Project (e.g., Aoyama 2007, 2009; Bachand 2006; Buechler 2012; Eberl 2007, 2014; Emery 2003; Emery and Aoyama 2007; Inomata 2001; Inomata and Triadan 2010, 2014; Inomata et al. 2001, 2002, 2004, 2009; Ishihara 2007; Terry et al. 2004; Triadan 2007).

These investigations substantially increased our understanding of social and political processes in the Pasión region. We should add, however, that these subsequent investigations largely focused on the Classic period, with notable exceptions of Johnston's (2006) study of Preclassic remains in the Itzan area and Bachand's (2006) excavation of Punta de Chimino as part of the Aguateca Archaeological Project. The study of the Preclassic period in the Pasión region was still underdeveloped. In 2005, we thought that it was important to return to the key site of the region, Ceibal, in the light of these new developments.

\section{Chronology of Ceibal}

Although the main purpose of this paper is to review the state of knowledge prior to our research at Ceibal that led to the specific design of our investigation, it is important to summarize the current chronological framework that incorporates the results of our research as well (Figure 2). Sabloff (1975) analyzed the

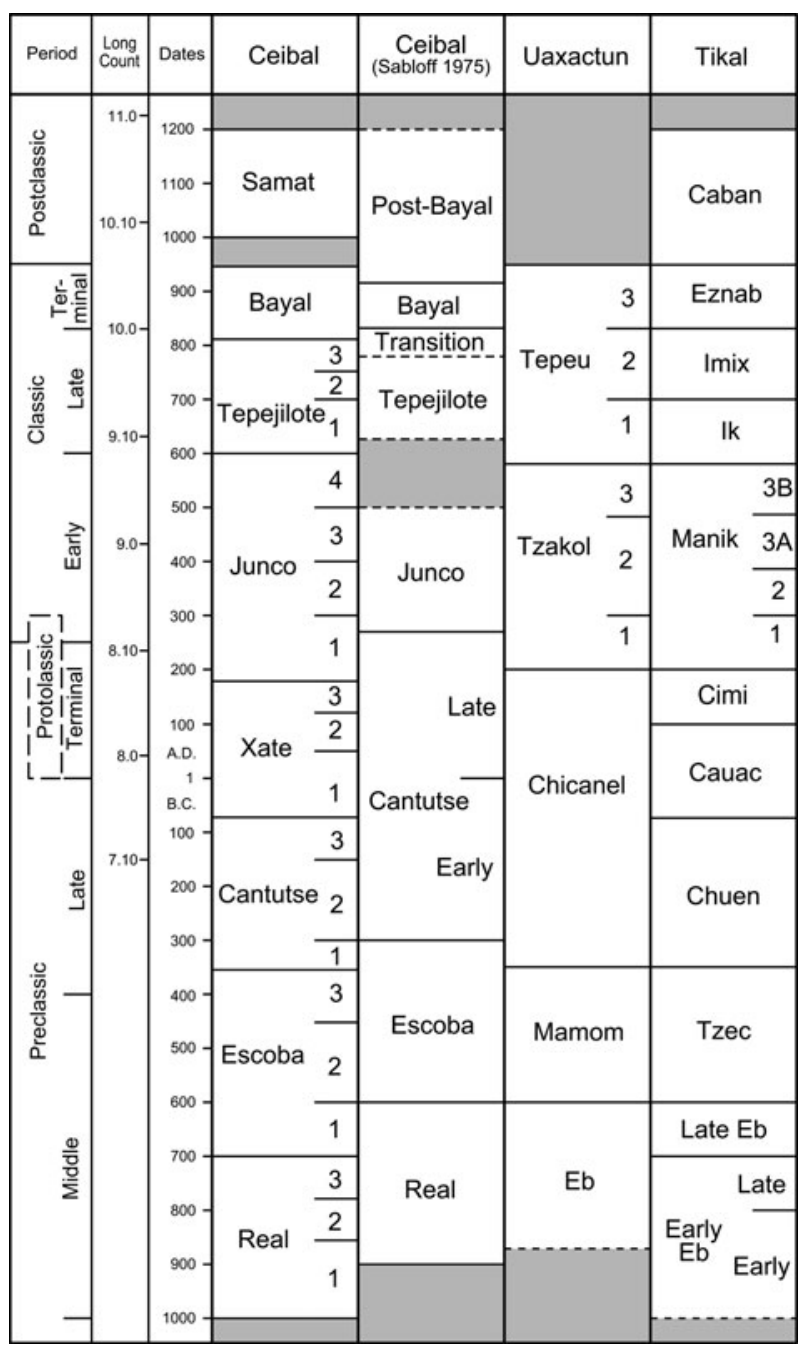

Figure 2. Chronologies of Ceibal and related sites. Chart by Inomata. 
ceramics excavated during the Harvard Project and established the original chronology of Ceibal with the following phases: the early Middle Preclassic Real-Xe (900-600 B.C.), the late Middle Preclassic Escoba-Mamom (600-300 B.C.), Late Preclassic Cantutse-Chicanel (300 B.C.-A.D. 250), Early Classic Junco (A.D. 250-500) followed by a period of abandonment, Late Classic Tepejilote (A.D. 650-830), and Terminal Classic Bayal (A.D. 830-950). This chronology was based on one radiocarbon date from a Preclassic context, as well as additional Classic-period radiocarbon dates and cross-dating with other sites. Our research showed that Sabloff's chronology was sound, while we were able to refine it further through additional ceramic data and radiocarbon dates. The 73 radiocarbon dates that we obtained from the Middle Preclassic contexts have been published (Inomata et al. 2013, 2015b), and we are currently preparing a paper that discusses the ceramic sequence.

For the early Middle Preclassic period, Inomata subdivided the Real-Xe phase into three facets: Real 1 (1000-850 B.C.), Real 2 (850-775 B.C.), and Real 3 (775-700 B.C.). The revision of ceramic samples stored at the Instituto de Antropología e Historia de Guatemala has led Inomata to suggest that the Xe ceramics from Altar de Sacrificios largely corresponds to the Real 3 phase. The late Middle Preclassic Escoba-Mamom phase was also subdivided into three parts: Escoba 1 (700-600 B.C.), Escoba 2 (600-450 B.C.), and Escoba 3 (450-350 B.C.). Sabloff originally divided the Late Preclassic Cantutse-Chicanel phase into early and late facets. As we subdivided this period, we felt it appropriate to separate the late facet as a new phase, which we named Xate. In our chronology, the Late Preclassic period generally refers to our re-defined Cantutse phase, including Cantutse 1 (350-300 B.C.), Cantutse 2 (300-150 B.C.), and Cantutse 3 (150-75 B.C.), and the Terminal Preclassic to the Xate phase, including Xate 1 (75 B.C.-A.D. 50), and Xate 2 (A.D. 50-125), and Xate 3 (A.D. 125-200). The Early Classic period is subdivided into four facets: Junco 1 (A.D. 200-300), Junco 2 (A.D. 300-400), Junco 3 (A.D. 400-500), and Junco 4 (A.D. 500-600). The Xate phase corresponds to the Protoclassic 1 facet established by Brady et al. (1998), whereas the Junco 1 phase to the Protoclassic 2 facet by Brady et al. and Manik 1 at Tikal (Laporte 1998; Laporte and Fialko 1987). We also use the term Protoclassic to loosely include the Xate and Junco 1 phase.

Junco 2 correlates to Manik 2 and the early part of Tzakol 2 at Uaxactun (Smith 1955), Junco 3 to Manik 3A (Laporte and Iglesias 1992) and the late part of Tzakol 2 characterized by Teotihuacan-like ceramic traits, and Junco 4 to Manik 3B and Tzakol 3. The Harvard researchers suggested that Ceibal was largely abandoned from A.D. 450 to A.D. 600, but we suspect that a small population continued during the Junco 3 and 4 phases. The divisions of the Late Classic period follow the chronology established in the Petexbatun region, at Aguateca, and at Nacimiento (Eberl 2014; Foias 1996; Foias and Bishop 1997, 2013; Inomata 2010): Tepejilote 1 (A.D. 600-700) corresponding to Tepeu 1 at Uaxactun; Tepejilote 2 (A.D. 700-750) to the early part of Tepeu 2 and Middle Nacimiento in the Petexbatun region; and Tepejilote 3 (A.D. 750-810) to Late Nacimiento, characterized by the introduction of ceramic attributes from the Usumacinta region. The Terminal Classic Bayal phase (A.D. 810-950), characterized by Fine Orange ceramics, was not subdivided, but we moved its inception slightly earlier than the original dating of A.D. 830 proposed by Sabloff. The Harvard researchers noted the presence of a small post-Bayal population (Sabloff 1975:224-228; Tourtellot
1988:223-225; 407-408), and we formally defined this Early Postclassic occupation as the Samat phase (A.D. 1000-1200).

\section{Early Middle Preclassic Real-Xe Phase (1000-700 B.c.)}

This period represents the beginning of sedentary village life at Ceibal. Although Archaic remains preceding this period have been found in Belize (Iceland 1997; Lohse 2010; Rosenswig et al. 2014), comparable evidence has not been detected in the Pasión region. Sediment cores taken from Laguna Tamarindito show evidence of probable forest disturbance and erosion starting around 1500 B.C. (Dunning et al. 1997). These data have led researchers to suspect that the Pasión region, as well as many parts of the Maya lowlands, was occupied by small mobile populations that practiced a mixed economy of horticulture, hunting, and gathering. Mueller et al. (2009), however, propose that these vegetation changes resulted largely from dry climate conditions, and the question of pre-ceramic populations needs to be further examined. The excavations by the Harvard Project showed Real ceramics were concentrated in Group A. In examining the map of Group A made by the Harvard researchers, Inomata noticed that the layout of this group resembled the plans of Gulf Coast and Chiapas centers rather than other Maya lowland centers (Figure 3). Particularly prominent aspects may include: (1) the north-south orientation of the overall site plan; (2) the centrality of an E-Group assemblage in the spatial plan and in public ceremonies; (3) the presence of large platforms that supported multiple structures around the E-Group assemblage; and 4) the use of clay in construction.

Following Lowe (1977, 1989) and McDonald (1983), Clark (Clark and Hansen 2001) has pointed out that this site layout

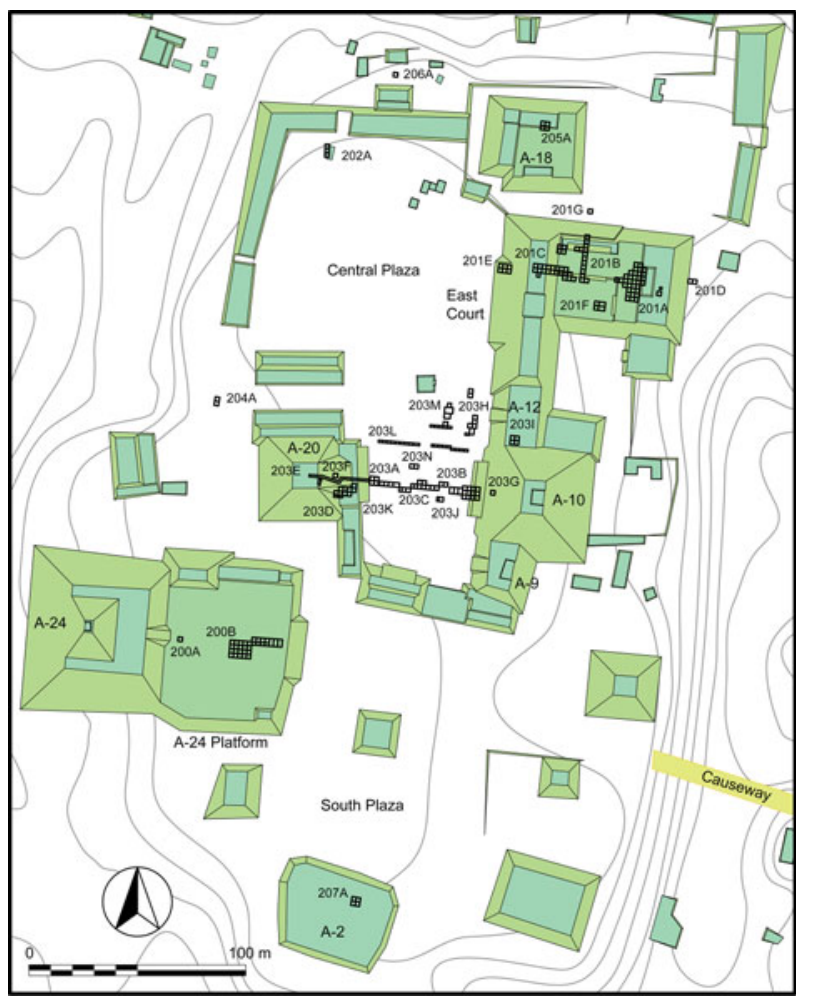

Figure 3. Map of Ceibal Group A with the locations of our excavations. Modified from Willey et al. 1975:Figure 2. Map by Jessica Munson and Inomata. 
spread along the Grijalva River in central Chiapas during the early Middle Preclassic period, including the centers of Mirador (a site different from the one in the central Maya lowlands) (Agrinier 1975, 2000), Chiapa de Corzo (Figure 4; Bachand and Lowe 2012; Hicks and Rosaire 1960; Lowe 1962; Lowe and Agrinier 1960; Mason 1960), Finca Acapulco (Lowe 1977, 2007), San Isidro (Figure 5; Lowe 1981), Ocozocoautla (McDonald 1999: 61-62), La Libertad (Figure 6; Miller 2014), possibly Vistahermosa (Treat 1986), as well as Tzutzuculi on the southern Pacific Coast (McDonald 1983). The results of recent research at Izapa by Rosenswig et al. (2013) suggest that this Chiapas Pacific piedmont center may have had this pattern as well. This may suggest that the residents of this area shared highly formalized ideas of religion, ritual, and community organization. Clark called this layout the Middle Formative Chiapas (MFC) pattern and speculated that this spatial plan and associated ideas originated at the Gulf Coast center of La Venta (Figure 7). The center of this site plan was the so-called E-Group assemblage, consisting of a pyramid on the west and a linear mound or three aligned structures on the east. Following Lowe $(1977,1989)$ and McDonald (1983), Clark and Hansen (2001) argue that the E-Group arrangement was first established at La Venta with Mounds D-1 and D-8.

E-Group assemblages were also ritual foci at many Preclassic Maya centers, including Tikal, Mirador, Nakbe, Uaxactun, Caracol, and Calakmul (Chase and Chase 1995; Hansen 1998; Laporte and Fialko 1995), and some scholars contend that this architectural arrangement originally developed in the central or eastern Maya lowlands (Estrada-Belli 2011; Stanton and Freidel 2003; Valdés 1995). Unlike the Chiapas counterparts, E-Group assemblages in the Maya lowlands were usually not surrounded by large platforms, and their overall site plans appear to emphasize an east-west axis (Clark and Hansen 2001; Hansen 2005). At Ceibal, Structures

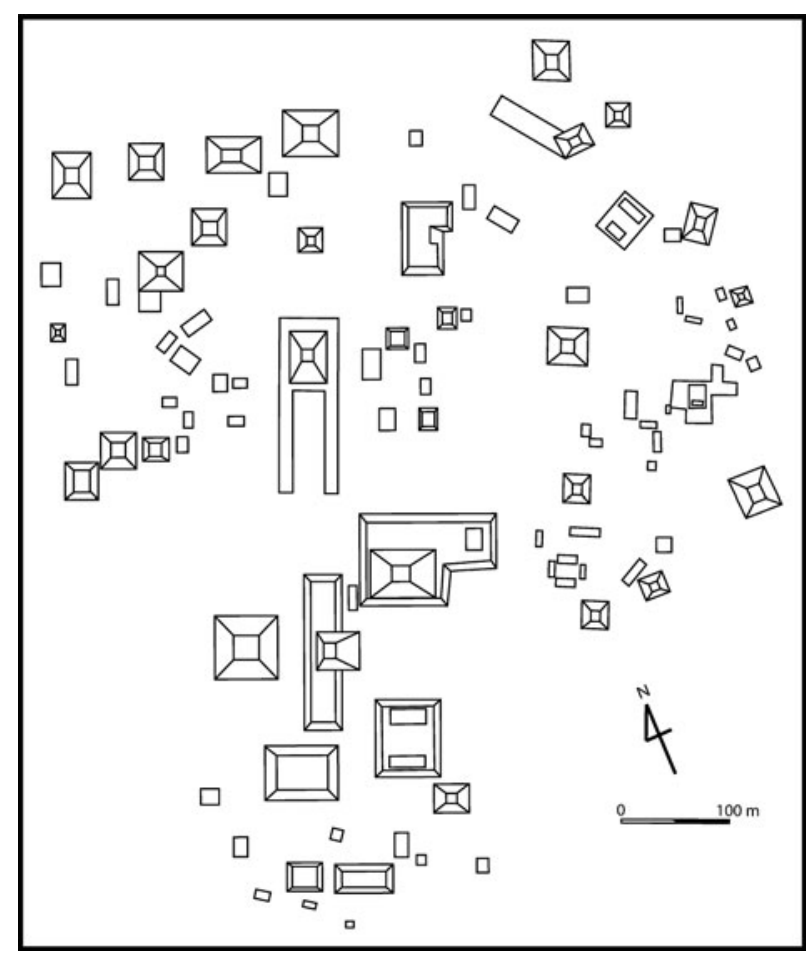

Figure 4. Map of Chiapa de Corzo. Drawing by Victor Castillo based on Bachand et al. 2008:Figure 2.

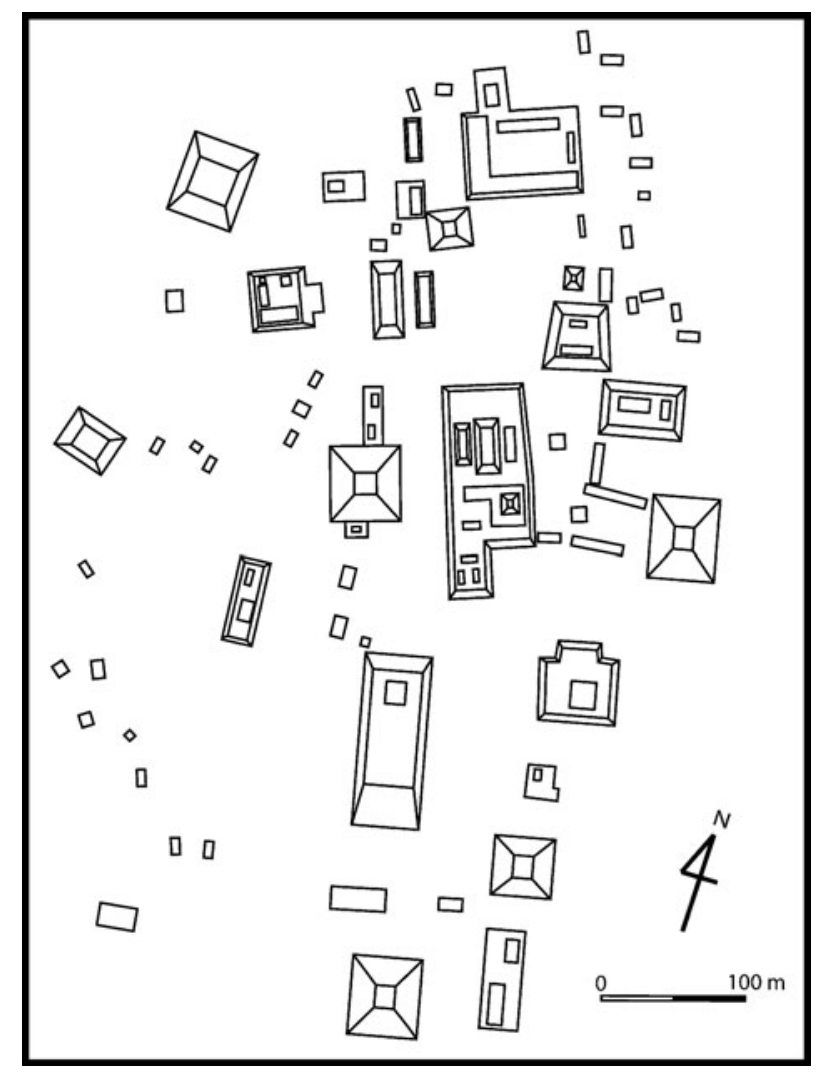

Figure 5. Map of San Isidro. Drawing by Victor Castillo based on Lee 1974:Figure 3.

A-20, A-9, A-10, and A-12 appeared to form an E-Group assemblage (Figure 3), but their Preclassic constructions had not been explored prior to our research. Along with this possible E-Group assemblage, large platforms-the A-24 platform, A-2 platform, the East Court, and A-18 platform-showed a layout arranged along a north-south axis. Excavations at Mirador (Agrinier 2000) and La Libertad (Clark and Hansen 2001) in Chiapas showed that these platforms supported multiple structures, which led the excavators to suggest that they were elite residential complexes.

Another line of evidence pointing to connections between Ceibal and Chiapas is the deposition of greenstone axe caches. Excavations along the central axis of the E-Group assemblage at San Isidro (Lowe 1981) and Chiapa de Corzo (Bachand and Lowe 2012) in central Chiapas revealed a series of caches containing greenstone axes, pseudo-axes, and other artifacts. The probable E-Group assemblage at La Venta has not been excavated systematically, and the presence of such remains needs to be tested by future research. Still, similar ritual practices are indicated by a series of greenstone caches unearthed in Complex A (Drucker et al. 1959). These deposits show that formalized spatial plans shared by the Chiapas centers and La Venta were tied to specific forms of ritual. Excavations by the Harvard archaeologists at Ceibal revealed a greenstone axe cache (Cache 7) in the southern part of the plaza of the probable E-Group assemblage (Smith 1982:245; Willey 1978: 86-98). Its cruciform shape resembled some of the caches found at San Isidro, Chiapa de Corzo, and La Venta. This find suggests that the residents of Ceibal conducted a ritual similar to those at the Chiapas centers, but the Harvard Project did not excavate the center line of the E-Group assemblage. Excavations by the 


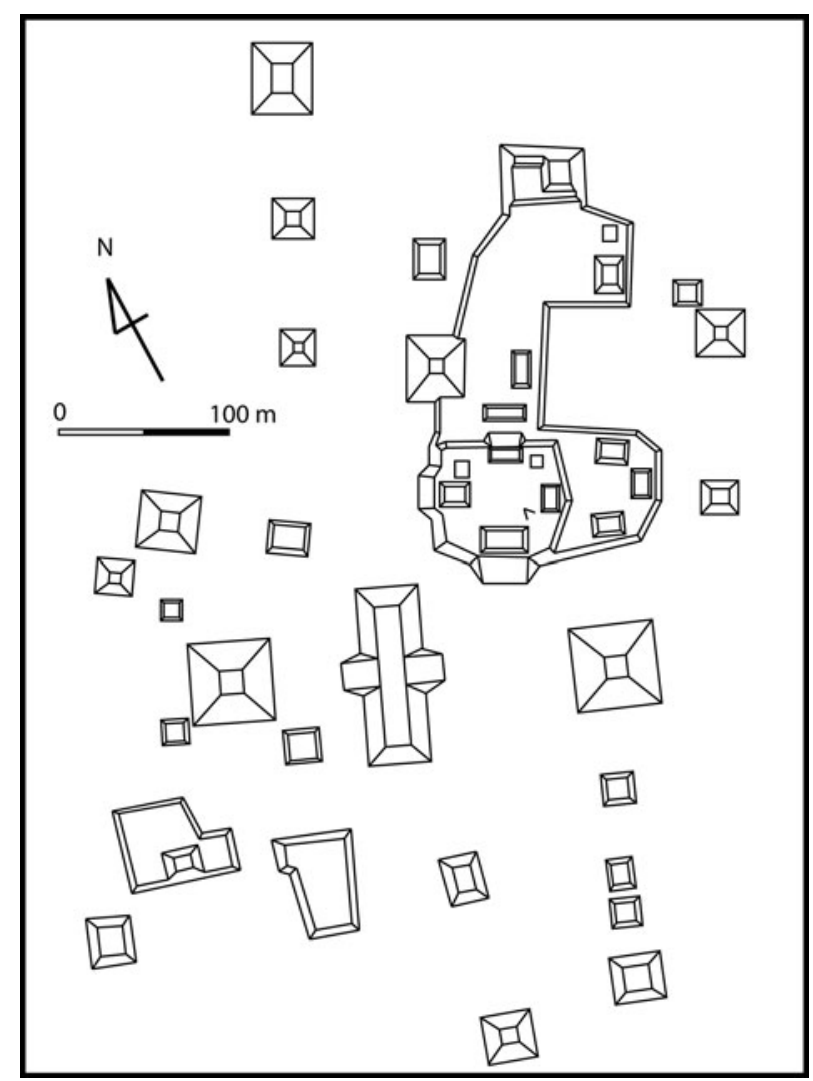

Figure 6. Map of La Libertad. Drawing by Victor Castillo based on Bryant et al. 2005:Figure 1.5.

Harvard Project did not detect any clear remains of Real-Xe phase buildings, and Harvard researchers suggested that Ceibal was a small village (Tourtellot 1988; Willey 1990:193). The possible presence of a formal ceremonial complex and associated ritual deposits led Inomata to question this interpretation.

In other parts of the Maya lowlands, E-Group assemblages dating to the Middle Preclassic period have been identified in the Mundo Perdido complex at Tikal (Laporte and Fialko 1995) and Cival (Estrada-Belli 2006). While a cruciform cache containing greenstone axes was found along the central axis of the Cival E-Group assemblage, the extensive excavation of the Mundo Perdido did not reveal a comparable deposit. Excavations at other lowland Maya sites, including Group E of Uaxactun (Ricketson and Ricketson 1937) have failed to uncover greenstone axe caches. In addition, the Middle Preclassic site plans of Tikal and Cival appear to lack large platforms arranged in a MFC pattern. Most lowland Maya sites do not exhibit the MFC pattern, and some appear to emphasize an east-west orientation of the overall plan (Clark and Hansen 2001). These differences and similarities in site plan present an intriguing question regarding the process of interaction and information flow between the Maya lowlands and Chiapas. Ceibal, located between the central Maya lowlands and Chiapas, appeared to hold a key to this question.

The ceramics of this period are also suggestive. Real-Xe ceramics are characterized by dull slips, markedly different from the waxy slips of later Mamom ceramics that spread throughout the Maya lowlands during the late Middle Preclassic period. Andrews (1990) has suggested that Real-Xe ceramics are similar to the

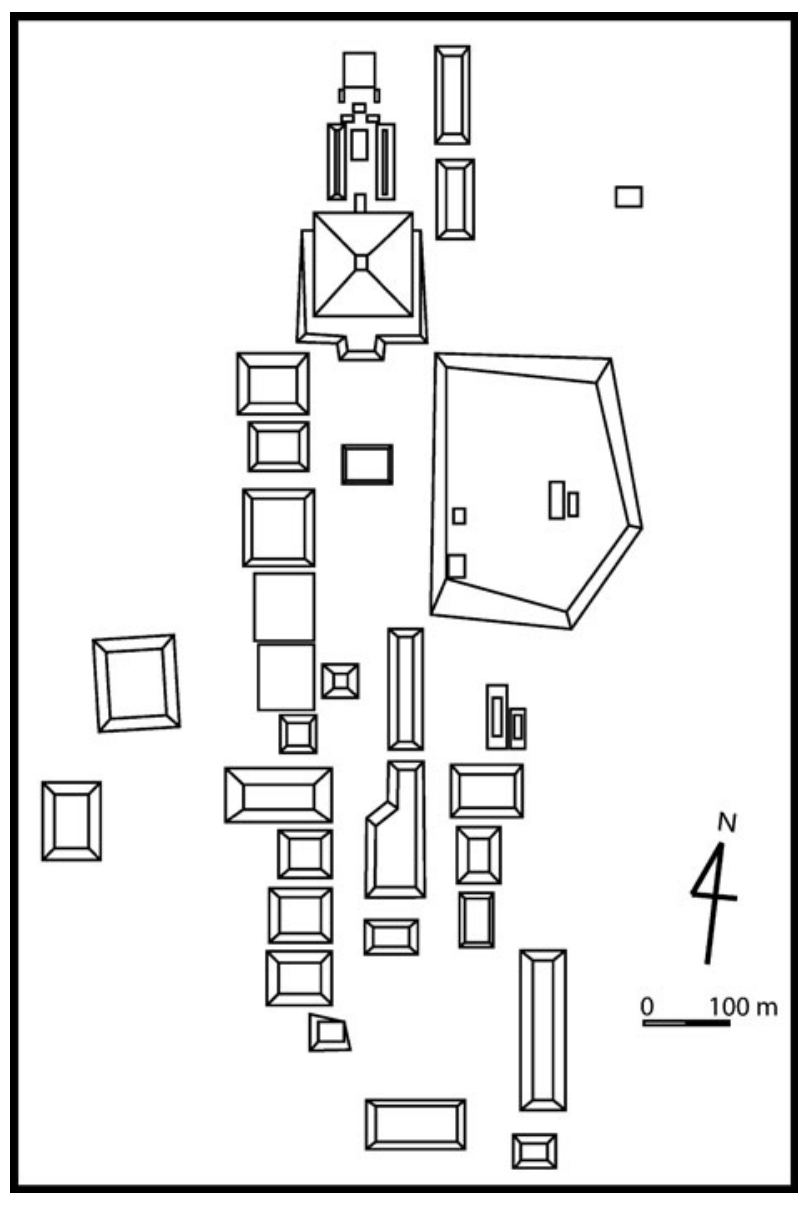

Figure 7. Map of La Venta. Drawing by Victor Castillo base on González Lauck 2010:Figure 6.1.

materials in the Chiapas highlands, whereas Clark and Cheetham (2002; Cheetham 2005) argue that the Real-Xe complex shares common traits with contemporaneous Maya lowland ceramics, particularly Eb ceramics in the central lowlands and Cunil ceramics in the eastern lowlands. We agree with Clark and Cheetham that the Real-Xe ceramics in a broad sense belonged to the lowland Maya ceramic sphere, but they also exhibited substantial differences from $\mathrm{Eb}$ and Cunil, possibly representing transitional forms or mixed traits between contemporaneous materials in Chiapas and in the central and eastern Maya lowlands.

We have a limited understanding of social organization of various groups involved in the interregional interaction during this period. At La Venta the presence of stone monuments and possible tombs with rich offerings points to an advanced degree of political centralization and social inequality with powerful rulers (Clark 1997). It is interesting to note that, outside the Gulf Coast, stone monuments that appear to depict political authorities were found along the Pacific Coast where E-Group complexes are absent, including Pijijiapan, Takalik Abaj, and Chalchuapa (Clark and Pye 2000). Tzutzuculi on the Pacific Coast is unique in this regard, as it possessed both an E-Group assemblage and stone monuments (McDonald 1983). In inland Chiapas, where E-Group assemblages are common, non-portable stone monuments depicting rulers appear to be absent with an exception of a stone carving at Xoc (Ekholm-Miller 1973). Still, the excavations of large platforms 
at Mirador (Agrinier 2000) and La Libertad (Clark and Hansen 2001) in Chiapas revealed middens and burials associated with structures built on them, and they may have been residential complexes of high-ranking groups. Although the artifacts found in burials and middens in these platforms at Mirador and $\mathrm{La}$ Libertad were not significantly different from those from other parts of the sites, their central locations and elevated settings may have set them apart from other residences.

Evidence of marked social inequality is virtually absent in the Maya lowlands during this period. Residences of this period found at Cuello, K'axob, and Blackman Eddy were built on the ground level or on low platforms, and noticeable differences in terms of architecture have not been found (Garber et al. 2004; Hammond 1991; McAnany 2004). In the latter part of the early Middle Preclassic, some burials at Cuello and K'axob contained larger quantities of greenstone and shell ornaments than others, suggesting some forms of social inequality, which may have been based largely on age and gender (Hammond 1999; McAnany et al. 1999).

\section{Late Middle Preclassic Escoba-Mamom Phase (700-350 B.c.)}

At the beginning of the Escoba-Mamom phase around 700 B.C. at Ceibal, the dull-slipped Real-Xe ceramics were replaced with the waxy-slipped Escoba-Mamom pottery. Ceibal now more firmly participated in the lowland Maya ceramic sphere, but it still retained some connections with Chiapas. Orange ceramics with resist decoration, Tierra Mojada Resist, which are far more common at Ceibal than in the central Maya lowlands, exhibited close similarities to the dominant ceramic group in Chiapas, Nicapa Orange.

The recent discovery of tombs in Mound 11 of Chiapa de Corzo, as well as other rich burials at Chiapa de Corzo and La Libertad, indicate that social inequality was well established in Chiapas during this period (Bachand and Lowe 2012). Nonetheless, materials found in probable elite residential complexes were not noticeably different from those from other residences. The nature of social inequality and political centralization during the late Middle Preclassic Maya lowlands is a point of debate. Substantial monumental buildings were erected at Nakbe (Hansen 1998), and smaller, yet considerable structures were built at other centers, including Tikal (Laporte and Fialko 1995), San Bartolo (Saturno et al. 2006), Blackman Eddy (Garber et al. 2004), and Cahal Pech (Aimers et al. 2000). Status differentiation is noted in burials at Cuello (Hammond 1999) and K'axob (McAnany and López Varela 1999; McAnany et al. 1999), but we do not have clear evidence of rulers.

In the Maya lowlands, masonry construction methods using locally available limestone were well established during this period. This technique contrasted with the heavy use of clay in the surrounding areas, including the southern Gulf Coast, Chiapas, the Guatemalan highlands, the Pacific Coast, Honduras, and El Salvador. It is probably that this difference in construction method reflected not only locally available materials but also different culture preferences.

Late Preclassic Cantutse-Chicanel Phase (350-75 B.C.) and the Protoclassic Xate-Junco 1 Phases (75 B.C.-A.D. 300)

At the end of the previous phase, La Venta, along with many of the Chiapas centers in the Grijalva River region, collapsed. This was a time of significant social change, but its impact on the Maya lowlands appears to have been limited. The inhabitants of the Maya lowlands shared various types of cultural practices even more clearly, including fairly homogeneous Chicanel ceramics. Clark and Hansen (2001) note that Maya cultural traits, including Chicanel ceramics and masonry constructions, spread to central Chiapas during this period. Ceibal was now firmly part of the lowland Maya sphere of shared cultural practices.

This period witnessed significant growth of Ceibal and other lowland Maya settlements. The population at Ceibal and its surroundings was at least several times larger than that of the previous phase (Tourtellot 1988). Although excavations of Preclassic monumental structures by the Harvard Project were limited, important data on Preclassic construction were obtained in the extensive excavation of Structure D-32. Stucco masks decorated a probable Protoclassic version of this pyramid (Smith 1982:212), reflecting an architectural style found at various lowland Maya sites during this period. Significant parts of the construction masses of large pyramids at Ceibal may date to the Late Preclassic and Protoclassic periods (Hammond 1984; Willey 1990). Ceibal appears to have been one of the most important centers in the southern Maya lowlands during these periods.

In the Late Preclassic and Protoclassic periods, clearer signs of ruling elites began to emerge in the Maya lowlands. Rich burials dating to the Late Preclassic (prior to $100 / 50$ B.C.) from the Maya lowlands are still rare, but important exceptions may include those recently found at San Bartolo and K'o (Saturno et al. 2006; Skidmore 2011). During the late part of the Late Preclassic and the Protoclassic, the notion of rulership appears to have been established. The San Bartolo murals, dating to 200-100 B.C., show scenes of coronation, and depictions of probable rulers and textual references to royal accessions are found in the Loltun Cave sculpture and the Dumbarton Oaks pectoral (Schele and Miller 1986:Plate 31). Elite tombs were also placed in the North Acropolis at Tikal (Coe 1990) and possibly at Wakna (Hansen 1998:90) toward the end of this time span. Important changes may also have been occurring at smaller centers. At Cuello and K'axob, residential groups with subfloor burials of the previous period were converted into public temple-plaza complexes (Hammond 1991; McAnany 2004; McAnany and López Varela 1999). McAnany (1995) has argued that the lineages of the original settlers enjoyed higher status than other occupants and eventually became ruling elites. The construction of temple-plaza complexes over residential groups may signify that the rituals and places originally tied to such groups were elevated to those of communal celebration. It is probable that the participants in these communal ceremonies were reminded each time of the unique status of the elite groups whose ancestors once occupied these spaces.

This social process may also be reflected in changes in the use of E-Group assemblages. For a large part of the Preclassic, E-Group assemblages at various sites may have been areas for deposits of caches (most of them are not cruciform axe caches) and not particularly rich burials. During the Protoclassic, however, deposits of elite burials in these areas may have begun, and placements of such interments may have become common during the Early Classic (Laporte and Fialko 1995; Chase and Chase 1995; Ricketson and Ricketson 1937). This change represents the conjoining of previous civic ceremonies with dynastic rituals (Chase and Chase 1995). During the Classic period, the association of these complexes with ruling elites became clearer, as stone monuments depicting rulers were also erected in E-Group plazas at various lowland Maya centers, including Uaxactun and Calakmul. The discovery of Stela 2 along the central axis of an E-Group assemblage at 
Cival shows that this pattern began during the Protoclassic period (Estrada-Belli 2006). It is probable that community members continued to participate in rituals held in these spaces, but their meanings were now substantially changed, forcing participants to experience new forms of social relations.

\section{CEIBAL-PETEXBATUN ARCHAEOLOGICAL PROJECT}

\section{Research Goals}

We initiated the Ceibal-Petexbatun Archaeological Project in 2005 with the objective of examining social change in the Maya lowlands during the Preclassic and Classic periods. In this special section of Ancient Mesoamerica, we focus largely on the Preclassic period. Architectural complexes in the core of Ceibal were the primary focus of this project. Through the analysis of their constructions, use, and alterations, we examined how the residents of Ceibal adopted, created, and modified ideas and practices through interactions with neighboring groups and in what kind of social contexts they did so. We also studied how architecture and space shaped and reflected the process of community-building and social transformation. Specific research questions included: (1) did the residents of Ceibal design their settlement in a configuration similar to those of Chiapas centers and adopt similar construction methods with the heavy use of clay? When did these constructions start?; (2) did they deposit caches comparable to those at the Chiapas centers and La Venta?; and (3) does the central ritual complex represent communal buildings, or was it used mainly by the emergent elite? How were changes in architecture and space tied to the process of political centralization and the development of social hierarchy?

If a ceremonial complex was indeed built during the Real-Xe phase in the standardized layout shared across regions, its construction must have marked a drastic change in this community. Small groups of mobile horticulturalists may have rapidly transformed into a sedentary community with an elaborate ritual complex. It might also suggest that Ceibal participated in the development of the ritual complex involving E-Group assemblages in southern Mesoamerica during its early stage. A related question was the construction method of this complex. The Classic-period version of the possible E-Group assemblage at Ceibal consisted of masonry construction (Smith 1982). If early buildings at Ceibal were built of clay and earth, they possibly represented stronger affinities with Chiapas or the Maya highlands. If early constructions were made of earth, it was important to examine when and how masonry techniques were adopted. Change in construction methods would imply a shift in interregional interaction patterns. The presence or absence of caches comparable to those found at the Chiapas centers also provided important information for understanding interregional interaction. The deposit of similar caches would imply that the residents of Ceibal shared specific ritual practices and ideas tied to the formal architectural arrangement with those of Chiapas and other areas. Another important question was whether the E-Group assemblage or other early ceremonial spaces were used mainly for communal rituals or for privileged groups. Rich caches and dedicatory interments of sacrificial victims may have been organized by the political authority, but they may also have represented a shared community ethos.

\section{Field Investigations}

The Ceibal-Petexbatun Archaeological Project has conducted field seasons every year since 2005, with the exception of 2007. In addition to Inomata, Triadan, and Aoyama, the research was led by Guatemalan co-directors: Ponciano in 2005 and 2006, Román from 2008 through 2010, Castillo from 2011 through 2012, Palomo in 2013, and Pinzón from 2014 through 2016. The articles in this Special Section focus primarily on the results from the project's inception through the 2012 season, when our operations concentrated on the Preclassic ceremonial complex in the site center and after which our original manuscripts were submitted to the journal. Some articles also incorporate the results from the subsequent seasons, which included minor operations in the site core and excavations in residential zones. Since we expected that early remains were under substantial constructions of later periods, we designed intensive excavations to address the aforementioned questions. An important focus was the probable E-Group assemblage consisting of Structures A-9, A-10, A-12, and A-20. In addition, we conducted a series of excavations in the plaza of this complex along its central axis to examine the presence of caches comparable to those at San Isidro and Chiapa de Corzo. In the course of these excavations, we noticed that early versions of the eastern building were buried under later plaza floors and we expanded excavations in the plaza to explore these constructions. The Special Section article by Inomata et al. (2017) reports the results of these operations. To investigate the construction dates of large platforms, we carried out deep excavations in the A-24 Platform, the East Court, and Structure A-18. The paper in this issue by Triadan et al. (2017) discusses their results. In addition, Munson and Pinzón conducted field investigations at the satellite center of El Caobal.

Field investigations followed the methods established during the Aguateca Archaeological Project (Inomata and Triadan 2010). Excavations followed two-by-two meter grid systems set along the orientations of structures. The grid system over the East Court guided the excavations of Operations 201A-G, and the same grid system was extended for Operations 205A and 206A. Operations 203A-J followed the grid system set for the Central Plaza, and Operations 200A and 200B used the one for the A-24 Platform. We created a separate grid system for each of Operations 202A, 204A, and 207A. Excavations followed natural stratigraphy whenever possible, and all excavated soils were screened with quarterinch or finer mesh. Excavation contexts and artifact proveniences are represented through a hierarchical designation system. For example, 203A4-5-1 refers to Operation 203 (generally a set of excavations of a group of structures), Suboperation A (excavations of a single structure or a substantial area), Unit 4 (a horizontal division that usually correspond to a two-by-two meter grid), Level 5 (a stratigraphic division), and Lot 1 (any subdivision within a unit and a level). According the system established for Aguateca, Level 1 always refers to the humus layer, Level 2 to the collapse, and Level 3 to materials found directly on the final occupation floor. Level 4 and beyond generally correspond to major construction stages, including construction fills and other layers below the final occupation floor. Floors are named by consecutive numbers from the final floor to the lower ones. When additional floors were found between named floors, we used alphabetical designations that could be followed by another set of consecutive numbers (e.g., Floors 3a, 3b, 4a1, 4a2, 4b, 5). We tried to use the same designation for continuations of the same floor in different excavation areas whenever possible, but in many cases such stratigraphic correlations were not immediately clear during excavation. Thus, floor numbers do not always correspond between different suboperations or different units within an extensive suboperation. Earlier structures below the final one were named Sub-1, Sub-2, 
and so on, from the penultimate one to earlier ones. Minor modifications may be represented with additions of alphabetical letters (e.g., Sub-3a, Sub-3b, Sub-4). When such stratigraphic sequences were not clear, we used Q'eqchi' or other names and added ordinal numbers for minor modifications (e.g., Sib' 1st, Sib' 2nd, and Sib' 3rd, from the latest to earliest).

These excavations revealed the earliest version of the E-Group assemblage and the A-24 Platform dating to 1000 B.C. These constructions predate other known examples of E-Group assemblages in the Maya lowlands, as well as most of comparable constructions in Chiapas (Inomata et al. 2013, 2015a, 2015b). Throughout the Middle Preclassic period, the E-Group assemblage at Ceibal was expanded, and early versions of the East Court and Structure A-18 were added. This process indicates that Ceibal was not a passive recipient of an architecture template and ritual developed elsewhere. The residents of Ceibal actively participated in interregional interaction involving the southern Gulf Coast, Chiapas, and the southern Pacific Coast, through which new forms of architectural arrangement and ritual, as well as associated social practices, emerged.

\section{RESUMEN}

El Proyecto Arqueológico Ceibal-Petexbatun ha llevado a cabo investigaciones de campo desde 2005 en el sitio de Ceibal ubicado en la parte suroeste de las tierras bajas mayas. Los trabajos anteriores realizados por la Universidad de Harvard nos permitieron desarrollar un plan de investigación detallado diseñado para preguntas específicas. Un enfoque importante del estudio fue cómo desarrolló la civilización de las tierras bajas mayas. A través de una comparación con los sitios contemporáneos de Chiapas central, se propuso una hipótesis que durante el período preclásico medio los residentes de Ceibal construyeron un patrón espacial formal que fue similar al de los centros de Chiapas. Las excavaciones concentraron en los elementos principales de este patrón espacial, incluyendo un probable conjunto arquitectónico tipo Grupo E (que consistió de una pirámide cuadrada en el oeste y una plataforma alargada en el este) y plataformas grandes (que puedan haber funcionado como complejos residenciales de las élites emergentes). Los resultados de estas excavaciones nos permiten examinar cómo los residentes de Ceibal participaron en las interacciones inter-regionales, incluyendo Chiapas, la Costa del Golfo, y otras áreas, y cómo actividades de construcción y arquitectura contribuyen a los procesos de cambios sociales.

\section{ACKNOWLEDGMENTS}

Investigations at Ceibal were carried out with permits generously issued by the Instituto de Antropología e Historia de Guatemala and were supported by grants from the National Geographic Society, the National Science Foundation (BCS-0750808), the National Endowment for the Humanities (RZ-51209-10), the Alphawood Foundation, and the Agnese Nelms Haury Program of the University of Arizona awarded to Inomata and Triadan, as well as funds from

\section{REFERENCES}

Adams, Richard E. W

1971 The Ceramics of Altar de Sacrificios, Guatemala. Papers of the Peabody Museum of Archaeology and Ethnology, Vol. 63, No. 1. Peabody Museum of Archaeology and Ethnology, Harvard University, Cambridge.

Agrinier, Pierre

1975 Mounds 9 and 10 at Mirador, Chiapas, Mexico. Papers of the New World Archaeological Foundation, No. 39. Brigham Young University, Provo.

2000 Mound 27 and the Middle Preclassic Period at Mirador, Chiapas, Mexico. Papers of the New World Archaeological Foundation, Vol. 58. Brigham Young University, Provo.

Aimers, James J., Terry G. Powis, and Jaime J. Awe

2000 Preclassic Round Structures of the Upper Belize River Valley. Latin American Antiquity 11:71-86.

Algaze, Guillermo

1989 The Uruk Expansion: Cross-cultural Exchange in Early Mesopotamian Civilization. Current Anthropology 30:571-608.

Anderson, Benedict

1991 Imagined Communities: Reflections on the Origin and Spread of Nationalism. Verso, London.

Andrews, E. Wyllys V.

1990 Early Ceramic History of the Lowland Maya. In Vision and Revision in Maya Studies, edited by Peter Harrison and Flora Clancy, pp. 1-19. University of New Mexico Press, Albuquerque.

Anthony, David

1990 Migration in Archeology: The Baby and the Bathwater. American Anthropologist 92:895-914.

Aoyama, Kazuo

2007 Elite Artists and Craft Producers in Classic Maya Society: Lithic the Japanese Ministry of Education, Culture, Sports, Science and Technology-Japan KAKENHI (21101003 and 21101002) and Japan Society for the Promotion of Science KAKENHI (21402008 and 26101003) awarded to Aoyama. We thank Wyllys Andrews, Norman Hammond, and Jeremy Sabloff, the members of the Harvard Project at Ceibal, who kindly read our early manuscript and provided thoughtful comments.

Evidence from Aguateca, Guatemala. Latin American Antiquity 18 $3-26$.

2009 Elite Craft Producers, Artists, and Warriors at Aguateca: Lithic Analysis. Aguateca Archaeological Project First Phase Monograph Series, Vol. 2. Takeshi Inomata and Daniela Triadan, series editors. University of Utah Press, Salt Lake City.

Ashmore, Wendy, and Jeremy A. Sabloff

2002 Spatial Orders in Maya Civic Plans. Latin American Antiquity 13: 201-215

Bachand, Bruce R.

2006 Preclassic Excavations at Punta de Chimino, Petén, Guatemala: Investigating Social Emplacement on an Early Maya Landscape. Ph.D. dissertation, School of Anthropology, University of Arizona, Tucson.

Bachand, Bruce R., Emiliano Gallaga Murrieta, and Lynneth S. Lowe

2008 The Chiapa de Corzo Archaeological Project: Report of the 2008 Field Season. Electronic document, http://chiapadecorzo.byu.edu/ Informes\%20y\%20publicaciones/Chiapa\%20de\%20Corzo\%202008_ English.pdf, accessed July 1, 2013.

Bachand, Bruce R., and Lynneth S. Lowe

2012 Chiapa de Corzo's Mound 11 Tomb and the Middle Formative Olmec. In Arqueología reciente de Chiapas: Contribuciones del encuentro celebrado en el $60^{\circ}$ aniversario de la Fundación Arqueológica Nuevo Mundo, edited by Lynneth S. Lowe and Mary E. Pye, pp. 45-68. Papers of the New World Archaeological Foundation, No. 72. Brigham Young University, Provo.

Barrett, John C.

1994 Fragments from Antiquity: An Archaeology of Social Life in Britain, 2900-1200 BC. Blackwell, Oxford.

Beach, Timothy, and Nicholas Dunning

1997 Ancient Maya Reservoir and Dam at Tamarindito, El Petén, Guatemala. Latin American Antiquity 8:20-29. 
Binford, Lewis R.

1965 Archaeological Systematics and the Study of Culture Process. American Antiquity 31:203-210.

Bloch, Maurice

1986 From Blessing to Violence: History and Ideology in the Circumcision Ritual of the Merina of Madagascar. Cambridge Studies in Social Anthropology, Vol. 61. Cambridge University Press, Cambridge.

Blomster, Jeffrey P., Hector Neff, and Michael D. Glascock

2005 Olmec Pottery Production and Export in Ancient Mexico Determined through Elemental Analysis. Science 307:1068-1072.

Bradley, Richard

1993 Altering the Earth: The Origins of Monuments in Britain and Continental Europe. Vol. 8. Society of Antiquaries of Scotland, Edinburgh.

Brady, James E.

1997 Settlement Configuration and Cosmology: The Role of Caves at Dos Pilas. American Anthropologist 99:602-618.

Brady, James E., Anne Scott, Alan Cobb, Irma Rodas, John Fogarty, and

Mónica Urquizú Sánchez

1997 Glimpses of the Dark Side of the Petexbatun Project: The Petexbatun Regional Cave Survey. Ancient Mesoamerica 9:17-38

Brady, James E., Joseph W. Ball, Ronald L. Bishop, Duncan C. Pring,

Norman Hammond, and R. A. Housley

1998 The Lowland Maya "Protoclassic": A Reconsideration of its Nature and Significance. Ancient Mesoamerica 8:353-364.

Braswell, Geoffrey E. (editor)

2003 The Maya and Teotihuacan: Reinterpreting Early Classic Interaction. University of Texas Press, Austin.

Bryant, Douglas Donne, John E. Clark, and David Cheetham

2005 Ceramic Sequence of the Upper Grijalva Region, Chiapas, Mexico. Papers of the New World Archaeological Foundation, No. 67. Brigham Young University, Provo.

Buechler, Jeff

2012 Maya Socio-Political Interaction and Domestic Architecture in the Petexbatun, Guatemala. Ph.D. dissertation, Department of Anthropology, University of Illinois Chicago, Chicago.

Cameron, Catherine

1995 Migration and the Movement of Southwestern Peoples. Journal of Anthropological Archaeology 14:104-124.

Canuto, Marcello A., and Jason Yaeger (editors)

2000 The Archaeology of Communities: A New World Perspective. Routledge, London.

Caso, Alfonso

1942 Definición y extensión del complejo "olmeca." In Mayas y Olmecas, Segunda Reunión de Mesa Redonda, pp. 43-46. Sociedad Mexicana de Antropología, Mexico City.

Chase, Arlen F., and Diane Z. Chase

1995 External Impetus, Internal Synthesis, and Standardization: E-Group Assemblages and the Crystallization of Classic Maya Society in the Southern Lowlands. In Emergence of Lowland Maya Civilization: The Transition from the Preclassic to the Early Classic, edited by Nikolai Grube, pp. 87-101. Acta Mesoamericana, Vol. 8. Verlag Anton Saurwein, Möckmühl.

Cheetham, David

2005 Cunil: A Pre-Mamom Horizon in the Southern Maya Lowlands. In New Perspectives on Formative Mesoamerican Cultures, edited by Terry G. Powis, pp. 27-38. BAR International Series, Vol. 1377. British Archaeological Reports, Oxford.

Ciudad Ruiz, Andrés, and Alfonso Lacadena

2006 La fundación de Machaquilá, Petén, en el Clásico Tardío maya. In Nuevas ciudades, nuevas patrias: Fundación y relocalización de ciudades en Mesoamérica y el Mediterráneo antiguo, edited by María Josefa Iglesias Ponce de León, Rogelio Valencia Rivera, and Andrés Ciudad Ruiz, pp. 149-181. Sociedad Española de Estudios Mayas, Madrid.

2008 Procesos históricos de reorientación durante el Clásico Terminal en Machaquilla. Mayab 20:145-160.

Clark, John E.

1997 The Arts of Government in Early Mesoamerica. Annual Review of Anthropology 26:211-234.

Clark, John E., and David Cheetham

2002 Mesoamerica's Tribal Foundations. In Archaeology of Tribal Societies, edited by W. A. Parkinson, pp. 278-339. Archaeological Series, Vol. 15. International Monographs in Prehistory, Ann Arbor.
Clark, John E., and Mary E. Pye

2000 The Pacific Coast and the Olmec Question. In Olmec Art and Archaeology in Mesoamerica, edited by John E. Clark and Mary E. Pye, pp. 217-251. National Gallery of Art, Washington, DC.

Clark, John E., and Richard D. Hansen

2001 Architecture of Early Kingship: Comparative Perspectives on the Origins of the Maya Royal Court. In Royal Courts of the Ancient Maya, Volume 2: Data and Case Studies, edited by Takeshi Inomata and Stephen D. Houston, pp. 1-45. Westview Press, Boulder.

Coe, William R.

1990 Excavations in the Great Plaza, North Terrace and North Acropolis of Tikal. Tikal Report, No. 14. University Museum, University of Pennsylvania, Philadelphia.

Cohen, Anthony P.

1985 The Symbolic Construction of Community. Tavistock, London.

Crow, Graham, and Allan Graham

1994 Community Life: An Introduction to Local Social Relations. Harvester Wheatsheaf, Hemel Hempstead.

Cyphers, Ann

2004 Escultura olmeca de San Lorenzo Tenochtitlán. Instituto de Investigaciones Antropológicas, Universidad Nacional Autónoma de México, Mexico City.

1997 Población, subsistencia y medio ambiente en San Lorenzo Tenochtitlan. Universidad Nacional Autónoma de México, Mexico City.

Demarest, Arthur A.

1989 The Olmec and the Rise of Civilization in Eastern Mesoamerica. In Regional Perspectives on the Olmec, edited by Robert J. Sharer and David C. Grove, pp. 303-344. Cambridge University Press, Cambridge.

1997 The Vanderbilt Petexbatun Regional Archaeological Project 1989-1994: Overview, History, and Major Results of a Multidisciplinary Study of the Classic Maya Collapse. Ancient Mesoamerica 8:209-228.

2006 The Petexbatun Regional Archaeological Project: A Multidisciplinary Study of the Collapse of a Classic Maya Kingdom. Vanderbilt Institute of Mesoamerican Archaeology Series, Vol. 1. Vanderbilt University Press, Nashville.

2013 Ideological Pathways to Economic Exchange: Religion, Economy, and Legitimation at the Classic Maya Royal Capital of Cancuén. Latin American Antiquity 24:371-402.

Demarest, Arthur A., Chloé Andrieu, Paola Torres, Mélanie Forné, Tomás Barrientos, and Marc Wolf

2014 Economy, Exchange, and Power: New Evidence from the Late Classic Maya Port City of Cancuen. Ancient Mesoamerica 25: 187-219.

Demarest, Arthur A., Claudia Quintanilla, and José Samuel Suasnavar

2016 The Collapses in the West and the Violent Ritual Termination of the Classic Maya Capital Center of Cancuen: Causes and Consequences. In Ritual, Violence, and the Fall of the Classic Maya Kings, edited by Gyles Iannone, Brett Houk, and Sonja Schwake, pp. 159-186. University Press of Florida, Gainesville.

DeMarrais, Elizabeth, Luis Jaime Castillo, and Timothy Earle

1996 Ideology, Materialization, and Power Strategies. Current Anthropology 37:15-31.

Diehl, Richard A.

2004 The Olmecs: America's First Civilization. Thames and Hudson, London.

Diehl, Richard A., and Michael D. Coe

1995 Olmec Archaeology. In The Olmec World: Ritual and Rulership, edited by J. Guthrie and E. P. Benson, pp. 11-25. The Art Museum, Princeton University, Princeton.

Dietler, Michael

1997 The Iron Age in Mediterranean France: Colonial Encounters, Entanglements, and Transformations. Journal of World Prehistory 11:269-358.

Drucker, Philip, Robert F. Heizer, and Robert H. Squier

1959 Excavations at La Venta, Tabasco. Bureau of American Ethnology Bulletin, Vol. 170. Smithsonian Institution, Washington, DC.

Dunning, Nicholas, Timothy Beach, and David Rue

1997 The Paleoecology and Ancient Settlement of the Petexbatun Region, Guatemala. Ancient Mesoamerica 8:255-266.

Dunning, Nicholas, David J. Rue, Timothy Beach, Alan Covich, and Alfred Traverse

1998 Human-Environment Interactions in a Tropical Watershed: The 
Paleoecology of Laguna Tamarindito, El Petén, Guatemala. Journal of Field Archaeology 25:139-151.

Earle, Timothy $\mathrm{K}$

1987 Chiefdoms in Archaeological and Ethnohistorical Perspective. Annual Review of Anthropology 16:279-308.

Eberl, Markus

2007 Community Heterogeneity and Integration: The Maya Sites of Nacimiento, Dos Ceibas, and Cerro de Cheyo, El Peten, Guatemala during the Late Classic. Ph.D. dissertation, Department of Anthropology, Tulane University, New Orleans.

2014 Community and Difference: Change in Late Classic Maya Villages of the Petexbatun Region. Vanderbilt Institute of Mesoamerican Archaeology Series, Vol. 8. Vanderbilt University Press, Nashville.

Ekholm-Miller, Susanna

1973 The Olmec Rock Carving at Xoc, Chiapas, Mexico. Papers of the New World Archaeological Foundation, No. 32. Brigham Young University, Provo.

Emery, Kitty F.

1997 The Maya Collapse: A Zooarchaeological Investigation. Ph.D. dissertation, Department of Anthropology, Cornell University, Ithaca.

2003 The Noble Beast: Status and Differential Access to Animals in the Maya World. World Archaeology 34:498-515.

Emery, Kitty F., and Kazuo Aoyama

2007 Bone, Shell, and Lithic Evidence for Crafting in Elite Maya Households at Aguateca, Guatemala. Ancient Mesoamerica 18:69-89.

Estrada-Belli, Francisco

2006 Lightning Sky, Rain, and the Maize God: The Ideology of Preclassic Maya Rulers at Cival, Peten, Guatemala. Ancient Mesoamerica 17:57-78.

2011 The First Maya Civilization: Ritual and Power before the Classic Period. Routledge, London.

Fields, Virginia M.

1991 The Iconographic Heritage of the Maya Jester God. In Sixth Palenque Round Table, 1986, edited by Merle Greene Robertson and Virginia M. Fields, pp. 167-174. University of Oklahoma Press, Norman.

Flannery, Kent V.

1968 The Olmec and the Valley of Oaxaca: A Model for Inter-regional Interaction in Formative Times. In Dumbarton Oaks Conference on the Olmec, October 28th and 29th, 1967, edited by Elizabeth P. Benson, pp. 79-117. Dumbarton Oaks Research Library and Collection, Washington, DC.

Foias, Antonia E.

1996 Changing Ceramic Production and Exchange Systems and the Classic Maya Collapse in in the Petexbatun Region. Ph.D. dissertation, Department of Anthropology, Vanderbilt University, Nashville.

Foias, Antonia E., and Ronald L. Bishop

1997 Changing Ceramic Production and Exchange in the Petexbatun Region, Guatemala: Reconsidering the Classic Maya Collapse. Ancient Mesoamerica 8:275-292.

2013 Ceramics, Production, and Exchange in the Petexbatun Region: The Economic Parameters of the Classic Maya Collapse. Vanderbilt Institute of Mesoamerican Archaeology Series, Vol. 7. Vanderbilt University Press, Nashville.

Foucault, Michel

1977 Discipline and Punish: The Birth of the Prison. Pantheon, New York.

Freidel, David A.

1990 The Jester God: The Beginning and End of a Maya Royal Symbol. In Vision and Revision in Maya Studies, edited by Flora S. Clancy and Peter D. Harrison, pp. 67-78. University of New Mexico Press, Albuquerque.

Garber, James F., M. Kathryn Brown, Jaime Awe, and Christopher J.

Hartman

2004 Middle Formative Prehistory of the Central Belize Valley. In The Ancient Maya of the Belize Valley: Half a Century of Archaeological Research, edited by James F. Garber, pp. 25-47. University Press of Florida, Gainesville.

González Lauck, Rebecca B.

2010 The Architectural Setting of Olmec Sculpture Clusters at La Venta, Tabasco. In The Place of Stone Monuments: Context, Use, and Meaning in Mesoamerica's Preclassic Tradition, edited by Julia
Guernsey, John E. Clark, and Bárbara Arroyo, pp. 177-205. Dumbarton Oaks Research Library and Collection, Washington, DC. Graham, John A.

1990 Excavations at Seibal, Department of Peten, Guatemala: Monumental Sculpture and Hieroglyphic Inscriptions. Memoirs of the Peabody Museum of Archaeology and Ethnology, Vol. 14, No. 1. Gordon R. Willey, series editor. Harvard University Press, Cambridge.

Grove, David C.

1989 Olmec: What's In A Name? In Regional Perspectives on the Olmec, edited by Robert J. Sharer and David C. Grove, pp. 8-14. Cambridge University Press, Cambridge.

1997 Olmec Archaeology: A Half Century of Research and its Accomplishments. Journal of World Prehistory 11:51-101.

Grove, David C., and Susan D. Gillespie

1992 Ideology and Evolution at the Pre-State Level: Formative Period Mesoamerica. In Ideology and Pre-Columbian Civilizations, edited by Arthur A. Demarest and Geoffrey W. Conrad, pp. 15-36. School of American Research Press, Santa Fe.

Hammond, Norman

1984 Review of Excavations at Seibal, Department of Peten, Guatemala. Major Excavations and Caches, etc., edited by Gordon R. Willey. Antiquaries Journal 64:119-121.

1989 Cultura Hermana: Reappraising the Olmec. Quarterly Review of Archaeology 9:1-4.

1999 The Genesis of Hierarchy: Mortuary and Offertory Ritual in the Pre-Classic at Cuello, Belize. In Social Patterns in Pre-Classic Meosamerica, edited by David C. Grove and Rosemary A. Joyce, pp. 49-66. Dumbarton Oaks Research Library and Collection, Washington, DC.

Hammond, Norman (editor)

1991 Cuello: An Early Maya Community in Belize. Cambridge University Press, Cambridge.

Hansen, Richard D.

1998 Continuity and Disjunction: The Pre-Classic Antecedents of Classic Maya Architecture. In Function and Meaning in Classic Maya Architecture, edited by Stephen D. Houston, pp. 49-122. Dumbarton Oaks Research Library and Collection, Washington, DC.

2005 Perspectives on Olmec-Maya Interaction in the Middle Formative Period. In New Perspectives on Formative Mesoamerican Cultures, edited by Terry G. Powis, pp. 51-72. BAR International Series, Vol. 1377. British Archaeological Reports, Oxford.

Helms, Mary W.

1988 Ulysses' Sail: An Ethnographic Odyssey of Power, Knowledge, and Geographical Distance. University of Texas Press, Austin.

1998 Access to Origins: Affines, Ancestors, and Aristocrats. University of Texas Press, Austin.

Hicks, Frederick, and Charles E. Rosaire

1960 Mound 13, Chiapa de Corzo, Chiapas, Mexico. Papers of the New World Archaeological Foundation, No. 10. Brigham Young University, Provo.

Houston, Stephen D.

1993 Hieroglyphs and History at Dos Pilas: Dynastic Politics of the Classic Maya. University of Texas Press, Austin.

Iceland, Harry B.

1997 The Preceramic Origins of the Maya: The Results of the Colha Preceramic Project in Northern Belize. Ph.D. dissertation, Department of Anthropology, University of Texas, Austin.

Inomata, Takeshi

1997 The Last Day of a Fortified Classic Maya Center: Archaeological Investigations at Aguateca, Guatemala. Ancient Mesoamerica 8: 337-351.

2007 Warfare and the Fall of a Fortified Center: Archaeological Investigations at Aguateca. Vanderbilt Institute of Mesoamerican Series, Vol. 3. Vanderbilt University Press, Nashville.

2001 The Power and Ideology of Artistic Creation: Elite Craft Specialists in Classic Maya Society. Current Anthropology 42: 321-333.

2006 Plazas, Performers, and Spectators: Political Theaters of the Classic Maya. Current Anthropology 47:805-842.

2013 Negotiation of Inalienability and Meanings at the Classic Maya Center of Aguateca, Guatemala. In The Inalienable in the Archaeology of Mesoamerica, edited by Brigitte Kovacevich and Michael G. Callaghan, pp. 128-141. Archaeological Papers of the American 
Anthropological Association, Vol. 23. American Anthropological Association, Arlington.

2014 War, Violence, and Society in the Maya Lowlands. In Embattled Bodies, Embattled Places: War in Pre-Columbian Mesoamerica and the Andes, edited by Andrew K. Scherer and John W. Verano, pp. 25-56. Dumbarton Oaks Research Library and Collection, Washington, DC.

Inomata, Takeshi, and Daniela Triadan

2009 Culture and Practice of War in Maya Society. In Warfare in Cultural Context: Practice, Agency, and the Archaeology of Violence, edited by Axel E. Nielsen and William H. Walker, pp. 56-83. University of Arizona Press, Tucson.

Inomata, Takeshi, and Daniela Triadan (editors)

2010 Burned Palaces and Elite Residences of Aguateca: Excavations and Ceramics. Aguateca Archaeological Project First Phase Monograph Series, Vol. 1. Takeshi Inomata and Daniela Triadan, series editors. University of Utah Press, Salt Lake City.

Inomata, Takeshi, and Daniela Triadan (editors)

2014 Life and Politics at the Royal Court of Aguateca: Artifacts, Analytical Data, and Synthesis. Aguateca Archaeological Project First Phase Monograph Series, Vol. 3. Takeshi Inomata and Daniela Triadan, series editors. University of Utah Press, Salt Lake City.

Inomata, Takeshi, Daniela Triadan, Erick Ponciano, and Kazuo Ayama

(editors)

2009 La política de lugares y comunidades en la antigua sociedad maya de Petexbatun: Las investigaciones del Proyecto Arqueológico Aguateca Segunda Fase. Ministerio de Cultura y Deportes, Dirección General del Patrimonio Cultural y Natural, and Instituto de Antropología e Historia, Guatemala City.

Inomata, Takeshi, Daniela Triadan, Erick Ponciano, Richard Terry, and

Harriet F. Beaubien

2001 In the Palace of the Fallen King: The Royal Residential Complex at the Classic Maya Center of Aguateca, Guatemala. Journal of Field Archaeology 28:287-306.

Inomata, Takeshi, Daniela Triadan, Erick Ponciano, Estela Pinto, Richard E. Terry, and Markus Eberl

2002 Domestic and Political Lives of Classic Maya Elites: The Excavation of Rapidly Abandoned Structures at Aguateca, Guatemala. Latin American Antiquity 13:305-330.

Inomata, Takeshi, Daniela Triadan, Kazuo Aoyama, Victor Castillo, and

Hitoshi Yonenobu

2013 Early Ceremonial Constructions at Ceibal, Guatemala, and the Origins of Lowland Maya Civilization. Science 340:467-471.

Inomata, Takeshi, Erick Ponciano, Oswaldo Chinchilla, Otto Román,

Véronique Breuil-Martínez, and Oscar Santos

2004 An Unfinished Temple at the Classic Maya Center of Aguateca, Guatemala. Antiquity 78:798-811.

Inomata, Takeshi, Flory Pinzón, Juan Manuel Palomo, Ashley Sharpe, Raúl Ortíz, María Belén Méndez, and Otto Román

2017 Public Ritual and Interregional Interactions: Excavations of the Central Plaza of Group A, Ceibal. Ancient Mesoamerica 28:203-232. Inomata, Takeshi, Jessica MacLellan, Daniela Triadan, Jessica Munson,

Melissa Burham, Kazuo Aoyama, Hiroo Nasu, Flory Pinzon, and Hitoshi

Yonenobu

2015b Development of Sedentary Communities in the Maya Lowlands: Coexisting Mobile Groups and Public Ceremonies at Ceibal, Guatemala. Proceedings of the National Academy of Sciences of the United States of America 112:4268-4273.

Inomata, Takeshi, Jessica MacLellan, and Melissa Burham

2015a The Construction of Public and Domestic Spheres in the Preclassic Maya Lowlands. American Anthropologist 117:519-534.

Inomata, Takeshi, and Laura R. Stiver

1998 Floor Assemblages from Burned Structures at Aguateca, Guatemala: A Study of Classic Maya Households. Journal of Field Archaeology 25:431-452.

Inomata, Takeshi, and Lawrence S. Coben (editors)

2006 Archaeology of Performance: Theaters of Power, Community, and Politics. AltaMira Press, Lanham.

Ishihara, Reiko

2007 Bridging the Chasm Between Religion and Politics: Archaeological Investigations of the Grietas at the Late Classic Maya Site of Aguateca, Peten, Guatemala. Ph.D. dissertation, University of California, Riverside.
Johnston, Kevin J.

2004 The "Invisible" Maya: Minimally Mounded Residential Settlement at Itzán, Petén, Guatemala. Latin American Antiquity 15: 145-175.

2006 Preclassic Maya Occupation of the Itzan Escarpment, Lower Río de La Pasión, Petén, Guatemala. Ancient Mesoamerica 17:177-201.

Jones, Siân

1997 The Archaeology of Ethnicity: Constructing Identities in the Past and Present. Routledge, London.

Just, Bryan B.

2006 Visual Discourse of Ninth-Century Stelae at Machaquila and Seibal. Unpublished Ph.D. dissertation, Tulane University, New Orleans.

Joyce, Arthur

1993 Interregional Interaction and Social Development on the Oaxaca Coast. Ancient Mesoamerica 4:67-84.

Joyce, Rosemary A.

2004 Unintended Consequences?: Monumentality as a Novel Experience in Formative Mesoamerica. Journal of Archaeological Method and Theory 11:5-29.

Junker, Laura L

1993 Craft Goods Specialization and Prestige Goods Exchange in Philippine Chiefdoms of the Fifteenth and Sixteenth Centuries. Asian Perspectives 32:1-35.

Kardulias, Nick

1999 World-systems Theory in Practice: Leadership, Production, and Exchange. Rowman and Littlefield, Lanham.

Kovacevich, Brigitte

2007 Ritual, Crafting, and Agency at the Classic Maya Kingdom of Cancuen. In Mesoamerican Ritual Economy: Archaeological and Ethnological Perspectives, edited by E. Christian Wells and Karla L. Davis-Salazar, pp. 67-114. University Press of Colorado, Boulder.

2011 The Organization of Jade Production at Cancuen, Guatemala. In The Technology of Maya Civilization, Political Economy and Beyond in Lithic Studies, edited by Zachary X. Hruby, Geoffrey E. Braswell, and Oswaldo Chinchilla Mazariegos, pp. 151-163. Equinox, London.

2013 Craft Production and Distribution in the Maya Lowlands: A Jade Case Study. In Merchants, Markets, and Exchange in the Pre-Columbian World, edited by Kenneth G. Hirth and Joanne Pillsbury, pp. 255-282. Dumbarton Oaks Research Library and Collection, Washington, DC.

Kowalski, Jeff K.

1999 Mesoamerican Architecture as a Cultural Symbol. Oxford University Press, New York.

Laporte, Juan Pedro

1988 El Complejo Manik: Dos depósitos sellados, Grupo 6C-XVI, Tikal. In Ensayos de alfarería prehispánica e histórica de Mesoamerica, edited by Mari Carmen Serra Puche and Carlos Navarrete Cáceres, pp. 97-188. Instituto de Investigaciones Antropológicas and UNAM, Mexico City.

Laporte, Juan Pedro, and Vilma Fialko

1987 La cerámica del Clásico Temprano desde Mundo Perdido, Tikal: Una reevaluación. In Maya Ceramics: Papers from the 1985 Maya Ceramic Conference, edited by Robert Sharer and Prudence Rice, pp. 123-181. BAR International Series, Vol. 345. British Archaeological Reports, Oxford.

1995 Reencuentro con Mundo Perdido, Tikal, Guatemala. Ancient Mesoamerica 6:41-94.

Laporte, Juan Pedro, and María Josefa Iglesias

1992 Unidades cerámicas de la Fase Manik 3, Tikal, Guatemala. Cerámica de Cultura Maya 16:69-101.

Lee, Thomas A.

1974 Mound 4 Excavations at San Isidro, Chiapas, Mexico. Papers of the New World Archaeological Foundation, No. 34. Brigham Young University, Provo.

Lesure, Richard G.

1999 On the Genesis of Value in Early Hierarchical Societies. In Material Symbols: Culture and Economy in Prehistory, edited by John E. Robb, pp. 23-55. Center for Archaeological Investigations, Occasional Paper, Vol. 26. Southern Illinois University, Carbondale.

2004 Shared Art Styles and Long-Distance Contact in Early Mesoamerica. In Mesoamerican Archaeology, edited by Rosemary A. Joyce and Julia A. Hendon, pp. 73-96. Blackwell Publishing, Oxford. 
Lohse, Jon C.

2010 Archaic Origins of the Lowland Maya. Latin American Antiquity 21:312-352.

Love, Michael W.

1999 Ideology, Material Culture, and Daily Practice in Pre-Classic Mesoamerica: A Pacific Coast Perspective. In Social Patterns in Pre-Classic Meosamerica, edited by David C. Grove and Rosemary A. Joyce, pp. 127-153. Dumbarton Oaks Research Library and Collection, Washington, DC.

Lowe, Gareth W.

1962 Mound 5 and Minor Excavations, Chiapa de Corzo, Chiapas, Mexico. Papers of the New World Archaeological Foundation, No. 12. Brigham Young University, Provo.

1977 The Mixe-Zoque as Competing Neighbors of the Early Lowland Maya. In The Origins of Maya Civilization, edited by Richard E. W. Adams, pp. 197-248. University of New Mexico Press, Albuquerque.

1981 Olmec Horizon Defined in Mound 20, San Isidro, Chiapas. In The Olmec and their Neighbors, edited by Michael D. Coe and David Grove, pp. 231-256. Dumbarton Oaks Research Library and Collection, Washington, DC.

1989 The Heartland Olmec: Evolution of Material Culture. In Regional Perspectives on the Olmec, edited by Robert J. Sharer and David C. Grove, pp. 33-67. Cambridge University Press, Cambridge.

2007 Early Formative Chiapas: The Beginnings of Civilization in the Central Depression of Chiapas. In Archaeology, Art, and Ethnogenesis in Mesoamerican Prehistory: Papers in Honor of Gareth W. Lowe, edited by Lynneth S. Lowe and Mary E. Pye, pp. 63-108. Papers of the New World Archaeological Foundation, No. 68. Brigham Young University, Provo.

Lowe, Gareth W., and Pierre Agrinier

1960 Mound 1, Chiapa de Corzo, Chiapas, Mexico. Papers of the New World Archaeological Foundation, No. 8. Brigham Young University, Provo.

Maler, Teobert

1908 Explorations of the Upper Usumatsintla and Adjacent Region: Altar De Sacrificios, Seibal, Itsimté-Sácluk, Cankuen. Memoirs of the Peabody Museum of Archaeology and Ethnology, Vol. 4, No. 1. Harvard University Press, Cambridge.

Marcus, Joyce, and Kent V. Flannery

1996 Zapotec Civilization: How Urban Society Evolved in Mexico's Oaxaca Valley. Thames and Hudson, New York.

Mason, J. Alden

1960 Mound 12, Chiapa de Corzo, Chiapas, Mexico. Papers of the New World Archaeological Foundation, No. 9. Brigham Young University, Provo.

McAnany, Patricia A.

1995 Living with the Ancestors: Kinship and Kingship in Ancient Maya Society. University of Texas Press, Austin.

McAnany, Patricia A. (editor)

2004 K'axob: Ritual, Work and Family in an Ancient Maya Village. Monumenta Archaeologica, Vol. 22. Cotsen Institute of Archaeology, University of California Los Angeles, Los Angeles.

McAnany, Patricia A., Rebecca Storey, and Angela K. Lockard

1999 Mortuary Ritual and Family Politics at Formative and Early Classic K'Axob, Belize. Ancient Mesoamerica 10:129-146.

McAnany, Patricia A., and Sandra L. López Varela

1999 Re-Creating the Formative Maya Village of K'Axob: Chronology, Ceramic Complexes, and Ancestors in Architectural Context. Ancient Mesoamerica 10:147-168.

McDonald, Andrew J.

1983 Tzutzuculi: A Middle-Preclassic Site on the Pacific Coast of Chiapas, Mexico. Papers of the New World Archaeological Foundation, No. 47. New World Archaeological Foundation, Brigham Young University, Provo.

1999 Middle Formative Pyramidal Platform Complexes in Southern Chiapas, Mexico: Structure and Meaning. Unpublished Ph.D. dissertation, University of Texas, Austin.

McGuire, Randall $\mathrm{H}$.

1992 A Marxist Archaeology. Academic Press, San Diego.

Miller, Donald E.

2014 Excavations at La Libertad, a Middle Formative Ceremonial Center in Chiapas, Mexico. Papers of the New World Archaeological Foundation, No. 64. Brigham Young University, Provo.
Mills, Barbara J.

2004 The Establishment and Defeat of Hierarchy: Inalienable Possessions and the History of Collective Prestige Structures in the Pueblo Southwest. American Anthropologist 106:238-251.

Moore, Jerry D.

1996 Architecture and Power in the Ancient Andes: The Archaeology of Public Buildings. Cambridge University Press, Cambridge.

Mueller, Andreas D., Gerald A. Islebe, Michael B. Hillesheim, Dustin A.

Grzesik, Flavio S. Anselmetti, Daniel Ariztegui, Mark Brenner, and Jason H.

Curtis, David A. Hodell, and Kathryn A. Venz

2009 Climate Drying and Associated Forest Decline in the Lowlands of Northern Guatemala during the Late Holocene. Quaternary Research $71: 133-141$

Palka, Joel W.

1997 Reconstructing Classic Maya Socioeconomic Differentiation and the Collapse at Dos Pilas, Peten, Guatemala. Ancient Mesoamerica 8: 293-306.

Pool, Christopher A.

2007 Olmec Archaeology and Early Mesoamerica. Cambridge University Press, Cambridge.

Renfrew, Colin, and John F. Cherry (editors)

1986 Peer Polity Interaction and Socio-Political Change. Cambridge University Press, Cambridge.

Rice, Prudence M., and Robert J. Sharer

1987 Maya Ceramics: Papers from the 1985 Maya Ceramic Conference. BAR International Series, Vol. 345. British Archaeological Reports, Oxford.

Ricketson, Oliver G., and Edith B. Ricketson

1937 Uaxactun, Guatemala. Group E--1926-1931. Carnegie Institution of Washington Publication, Vol. 477. Carnegie Institution of Washington, Washington, DC.

Ringle, William M.

1999 Pre-Classic Cityscapes: Ritual Politics among the Early Lowland Maya. In Social Patterns in Pre-Classic Meosamerica, edited by David C. Grove and Rosemary A. Joyce, pp. 183-223. Dumbarton Oaks Research Library and Collection, Washington, DC.

Rosenswig, Robert M., Deborah M. Pearsall, Marilyn A. Masson, Brendan J. Culleton, and Douglas J. Kennett

2014 Archaic Period Settlement and Subsistence in the Maya Lowlands: New Starch Grain and Lithic Data from Freshwater Creek, Belize. Journal of Archaeological Science 41:308-321.

Rosenswig, Robert M., Ricardo López-Torrijos, Caroline E. Antonelli, and Rebecca R. Mendelsohn

2013 Lidar Mapping and Surface Survey of the Izapa State on the Tropical Piedmont of Chiapas, Mexico. Journal of Archaeological Science 40:1493-1507.

Rouse, Irving

1986 Migrations in Prehistory: Inferring Population Movement from Cultural Remains. Yale University Press, New Haven.

Sabloff, Jeremy A.

1975 Excavations at Seibal, Department of Peten, Guatemala: Ceramics. Memoirs of the Peabody Museum of Archaeology and Ethnology, Vol. 13, No. 2. Gordon R. Willey, series editor. Harvard University Press, Cambridge.

Saturno, William A., David Stuart, and Boris Beltrán

2006 Early Maya Writing at San Bartolo, Guatemala. Science:1281-1283.

Saturno, William A., Karl A. Taube, and David Stuart

2005 The Murals of San Bartolo, El Peten, Guatemala, Part 1: The North Wall. Ancient America 7:1-56.

Schele, Linda, and Mary Ellen Miller

1986 The Blood of Kings: Dynasty and Ritual in Maya Art. Kimbell Art Museum, Fort Worth.

Sharer, Robert J., Andrew K. Balkansky, James Burton, Gary M. Feinman,

Kent V. Flannery, David C. Grove, Joyce Marcus, Robert G. Moyle, T.

Douglas Price, Elsa M. Redmond, Robert G. Reynolds, Prudence M. Rice,

Charles S. Spencer, James B. Stoltman, and Jason Yaeger

2006 On the Logic of Archaeological Inference: Early Formative Pottery and the Evolution of Mesoamerican Societies. Latin American Antiquity 17:90-103.

Skidmore, Joel

2011 Earliest Jester God Found at K'o, Guatemala. Electronic document, http://www.mesoweb.com/reports/EarliestJesterGod.pdf, accessed July 1, 2013. 
Smith, A. Ledyard

1982 Excavations at Seibal, Department of Peten, Guatemala: Major Architecture and Caches. Memoirs of the Peabody Museum of Archaeology and Ethnology, Vol. 15, No. 1. Gordon R. Willey, series editor. Harvard University Press, Cambridge.

Smith, Adam T.

2003 The Political Landscape: Constellations of Authority in Early Complex Polities. University of California Press, Berkeley.

Smith, Robert E.

1955 Ceramic Sequence at Uaxactun, Guatemala. Publications of the Middle American Research Institute, No. 20. Tulane University, New Orleans.

Stanish, Charles

2001 The Origin of State Societies in South America. Annual Review of Anthropology 30:41-64.

Stanton, Travis W., and David A. Freidel

2003 Ideological Lock-in and the Dynamics of Formative Religions in Mesoamerica. Mayab 16:5-14.

Stark, Barbara L.

2000 Framing the Gulf Olmec. In Olmec Art and Archaeology in Mesoamerica, edited by John E. Clark and Mary E. Pye, pp. 31-54. National Gallery of Art, Washington, DC.

Stone, Andrea

1989 Disconnection, Foreign Insignia, and Political Expansion: Teotihuacan and the Warrior Stelae of Piedras Negras. In Mesoamerica after the Decline of Teotihuacan, A.D. 700-900, edited by Richard A. Diehl and Janet C. Berlo, pp. 153-172. Dumbarton Oaks Research Library and Collection, Washington, DC.

Sugiyama, Saburo

1993 Worldview Materialized in Teotihuacan, Mexico. Latin American Antiquity 4:103-129.

Symonds, Stacey, Ann Cyphers, and Roberto Lunagómez

2002 Asentamiento prehispánico en San Lorenzo Tenochtitlán. Serie San Lorenzo, Vol. 2. Universidad Nacional Autónoma de México, Instituto de Investigaciones Antropológicas: Dirección General de Asuntos del Personal Académico-Universidad Nacional Autónoma de México, Mexico City.

Taube, Karl A.

1985 Classic Maya Maize God: A Reappraisal. In Fifth Palenque Round Table, 1983, edited by Virginia M. Fields, pp. 171-181. Pre-Columbian Art Research Institute, San Francisco.

1996 Olmec Maize God: The Face of Corn in Formative Mesoamerica. RES: Anthropology and Aesthetics 29-30:39-81.

1998 The Jade Hearth: Centrality, Rulership, and the Classic Maya Temple. In Function and Meaning in Classic Maya Architecture, edited by Stephen D. Houston, pp. 427-478. Dumbarton Oaks Research Library and Collection, Washington, DC.

Terry, Richard E., Fabian G. Fernández, J. Jacob Parnell, and Takeshi Inomata

2004 The Story in the Floors: Chemical Signatures of Ancient and Modern Maya Activities at Aguateca, Guatemala. Journal of Archaeological Science 31:1237-1250.

Tourtellot III, Gair,

1988 Excavations at Seibal, Department of Peten, Guatemala: Peripheral Survey and Excavation, Settlement and Community Patterns. Memoirs of the Peabody Museum of Archaeology and Ethnology, Vol. 16. Gordon R. Willey, series editor. Harvard University Press, Cambridge.

Tourtellot, Gair, and Norman Hammond

2007 Serendipity at Seibal: Gordon Willey in the Pasión Valley. In Gordon R. Willey and American Archaeology, edited by Jeremy A. Sabloff and William L. Fash, pp. 126-140. University of Oklahoma Press, Norman.
Treat, Raymond

1986 Early and Middle Formative Sub-Mound Refuse Deposits at Vistahermosa, Chiapas. Notes of the New World Archaeological Foundation, No. 2. Brigham Young University, Provo.

Triadan, Daniela

2007 Warriors, Nobles, Commoners and Beasts: Figurines from Elite Buildings at Aguateca, Guatemala. Latin American Antiquity 18: 269-293.

Triadan, Daniela, Victor Castillo, Takeshi Inomata, Juan Manuel Palomo,

María Belén Méndez, Mónica Cortave, Jessica MacLellan, Melissa Burham, and Erick Ponciano

2017 Social Transformations in a Middle Preclassic Community: Elite Residential Complexes at Ceibal. Ancient Mesoamerica 28: 233-264.

Valdés, Juan Antonio

1995 Desarrollo cultural y señales de alarma entre los mayas: El preclásico tardío y la transición hacia el clásico temprano. In Emergence of Lowland Maya Civilization: The Transition from the Preclassic to the Early Classic, edited by Nikolai Grube, pp. 71-85. Acta Mesoamericana, Vol. 8. Verlag Anton Saurwein, Möckmühl.

Weiner, Annette B.

1992 Inalienable Possessions. University of California Press, Berkeley. Willey, Gordon R.

1973 The Altar de Sacrificios Excavations: General Summary and Conclusions. Papers of the Peabody Museum of Archaeology and Ethnology, Vol. 64, No. 3. Gordon R. Willey, series editor. Harvard University Press, Cambridge.

1978 Excavations at Seibal, Department of Peten, Guatemala: Artifacts. Memoirs of the Peabody Museum of Archaeology and Ethnology, Vol. 14, No. 1. Gordon R. Willey, series editor. Harvard University Press, Cambridge.

1990 Excavations at Seibal, Department of Peten, Guatemala: General Summary and Conclusions. Memoirs of the Peabody Museum of Archaeology and Ethnology, Vol. 17, No. 4. Gordon R. Willey, series editor. Harvard University Press, Cambridge.

Willey, Gordon R., A. Ledyard Smith, Gair Tourtellot III, and Ian Graham 1975 Excavations at Seibal, Department of Peten, Guatemala: Introduction: The Site and its Setting. Memoirs of the Peabody Museum of Archaeology and Ethnology, Vol. 13, No. 1. Gordon R. Willey, series editor. Harvard University Press, Cambridge.

Woodfill, Brent

2010 Ritual and Trade in the Pasión-Verapaz Region, Guatemala. Vanderbilt Institute of Mesoamerican Archaeology, Vol. 6. Vanderbilt University Press, Nashville.

2011 The Central Role of Cave Archaeology in the Reconstruction of Classic Maya Culture History and Highland-Lowland Interaction. Ancient Mesoamerica 22:213-227.

Woodfill, Brent, and Chloé Andrieu

2012 Tikal's Early Classic Domination of the Great Western Trade Route: Ceramic, Lithic, and Iconographic Evidence. Ancient Mesoamerica 23:189-209.

Woodfill, Brent, Stanley Guenter, and Mirza Monterroso

2012 Changing Patterns of Ritual Activity in an Unlooted Cave in Central Guatemala. Latin American Antiquity:93-119.

Wright, Lori E.

1997 Biological Perspectives on the Collapse of the Pasion Maya. Ancient Mesoamerica 8:267-273.

2006 Diet, Health, and Status among the Pasión Maya: A Reappraisal of the Collapse. 1st ed. Vanderbilt Institute of Mesoamerican Archaeology Series, Vol. 2. Vanderbilt University Press, Nashville.

Yoffee, Norman

2004 Myths of the Archaic State: Evolution of the Earliest Cities, States and Civilizations. Cambridge University Press, Cambridge. 